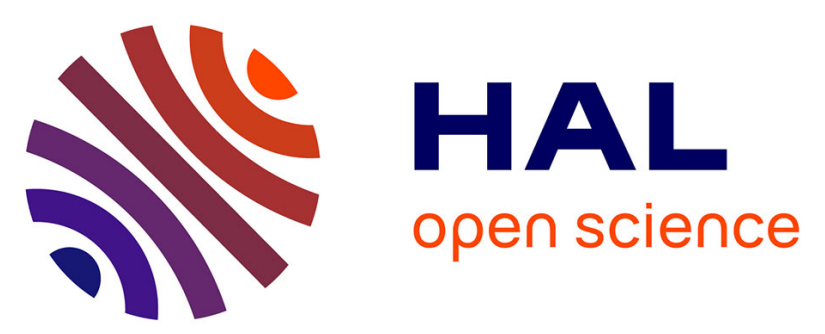

\title{
Origin, composition and quality of suspended particulate organic matter in relation to freshwater inflow in a South Texas estuary
}

Benoit Lebreton, Jennifer A Pollack, Brittany A Blomberg, Terence A Palmer, Leslie A Adams, Gaël Guillou, Paul A Montagna

\section{To cite this version:}

Benoit Lebreton, Jennifer A Pollack, Brittany A Blomberg, Terence A Palmer, Leslie A Adams, et al.. Origin, composition and quality of suspended particulate organic matter in relation to freshwater inflow in a South Texas estuary. Estuarine, Coastal and Shelf Science, 2016, 170, pp.70 - 82. 10.1016/j.ecss.2015.12.024 . hal-01447364

\section{HAL Id: hal-01447364 https://hal.science/hal-01447364}

Submitted on 26 Jan 2017

HAL is a multi-disciplinary open access archive for the deposit and dissemination of scientific research documents, whether they are published or not. The documents may come from teaching and research institutions in France or abroad, or from public or private research centers.
L'archive ouverte pluridisciplinaire HAL, est destinée au dépôt et à la diffusion de documents scientifiques de niveau recherche, publiés ou non, émanant des établissements d'enseignement et de recherche français ou étrangers, des laboratoires publics ou privés. 


\section{Origin, composition and quality of suspended particulate organic matter in relation to} freshwater inflow in a South Texas estuary

Benoit Lebreton ${ }^{\mathrm{a}, \mathrm{b}^{*}}$; Jennifer Beseres Pollack ${ }^{\mathrm{c}}$; Brittany Blomberg ${ }^{\mathrm{a}}$; Terence A. Palmer ${ }^{\mathrm{a}, \mathrm{c}}$; Leslie Adams $^{a}$; Gaël Guillou ${ }^{b}$; Paul A. Montagna ${ }^{a}$

${ }^{a}$ Harte Research Institute for Gulf of Mexico Studies, Texas A\&M University - Corpus Christi, 6300 Ocean Drive, Unit 5869, Corpus Christi, TX 78412-5869, USA.

${ }^{\mathrm{b}}$ UMR Littoral, Environment et Societies, CNRS - University of La Rochelle, Institut du Littoral et de I'environnement, 2 rue Olympe de Gouges, 17000 La Rochelle, France.

c Department of Life Sciences, Texas A\&M University - Corpus Christi, 6300 Ocean Drive, Unit 5800, Corpus Christi, TX 78412-5800, USA.

${ }^{*}$ Corresponding author. E-mail address: benoit.lebreton@univ-Ir.fr, Tel: + 33 (0)5 164967 31, Fax: +33 (0)546507663

E-mail addresses: Jennifer Beseres Pollack: jennifer.pollack@tamucc.edu; Brittany Blomberg: brittany.blomberg@tamucc.edu; Terence A. Palmer: terry.palmer@tamucc.edu; Leslie Adams: leslie.adams@tamucc.edu; Gaël Guillou: gguill01@univ-Ir.fr; Paul A. Montagna:

Paul.Montagna@tamucc.edu

\section{Abstract}

SPOM: suspended particulate organic matter; Chl a: chlorophyll a; GoM: Gulf of Mexico; POC: Particulate organic matter. 
South Texas has a semi-arid climate with a large interannual variability of freshwater inflows. This study sought to define how changes in freshwater inflow affect the composition, quantity and quality of suspended particulate organic matter (SPOM) in a South Texas estuary: the MissionAransas estuary. The study was implemented 1.5 months after a large rain event in September 2010 and continued for 10 months of drought conditions. The composition of SPOM originating from rivers, the Gulf of Mexico and the estuary were determined using stable isotopes $\left(\delta^{13} \mathrm{C}, \delta^{15} \mathrm{~N}\right.$ and $\left.\delta^{34} \mathrm{~S}\right)$. The quantity and quality of SPOM were assessed using organic carbon content, chlorophyll $a$ concentrations and $\mathrm{C} / \mathrm{chl} a$ ratios. Our results demonstrated that autochthonous phytoplankton was the dominant component of SPOM in the Mission-Aransas estuary during droughts. Benthic organic matter from local primary producers (i.e., seagrass, salt marsh plants, benthic microalgae) did not influence SPOM composition, either as fresh material or as detritus. A comparison with a positive estuary (i.e., Sabine-Neches estuary, TX) indicates that decreases in freshwater inflow may lead to decreases of terrestrial organic matter inputs and to increase the ratio of autochtonous phytoplanktonic material in SPOM.

\section{Highlights}

- Phytoplankton dominate particulate organic matter in the Mission-Aransas estuary.

- Benthic organic matter does not influence particulate organic matter composition.

- Organic matter drained by rivers during minor rain events is of very poor quality.

\section{Keywords}

Suspended particulate organic matter; Freshwater inflow; Stable isotope ratio; Chlorophyll $a$; Gulf of Mexico; Texas estuary

\section{Introduction}


Estuaries are among the most productive ecosystems on Earth, with production equal to that of

tropical rain forests (McLusky, 1989). The quantity and timing of freshwater delivery to the mixing zone is essential to their functioning (Montagna et al., 2002). Freshwater inflows play key roles in carrying continental organic matter from the watershed to the estuary (Hedges et al., 1997), and in balancing effects of tidal inputs of saltwater and of evaporation, consequently affecting the structure of habitats. As a result, freshwater inflows affect inputs of continental and marine organic matter and autochthonous pelagic and benthic primary production (Longley, 1995). Increasing human populations will result in an increasing demand for freshwater, which will affect freshwater inflow into estuaries and have consequences on the functioning of estuarine ecosystems (Montagna et al., 2002).

One consequence is the potential change of composition of suspended particulate organic matter (SPOM), an integral component of estuarine food webs (Longley, 1994). Organic matter locally produced in estuaries or provided by rivers or the sea varies in terms of quantity and quality depending on its origin and its state of decay (Dunton et al., 2001; Raymond and Bauer, 2001). This diversity of primary productions can be used by many different consumers, making highly complex estuarine food webs. Consequently, estuaries provide many ecological functions, including breeding grounds, nurseries and feeding sites for a large diversity of pelagic and benthic species (Beck et al., 2001). For example, SPOM is generally the main food source of suspension feeders like oysters. As a result, a change of abundance or composition of SPOM may severely affect the oyster diet (Riera and Richard, 1997), and therefore the general functioning of oyster reefs, which provide many ecological functions (Beck et al, 2011; Grabowski et al., 2012).

The origins, quantity, and quality of SPOM can be determined by measuring several variables, including stable isotope ratios, chlorophyll $a(\mathrm{chl} a)$ content and $\mathrm{C} / \mathrm{chl} a$ ratios. Stable isotope ratios of carbon and of sulfur provide information about the origin of organic matter. Stable isotopes of carbon allow for discrimination between the different estuarine primary producers (Fry and Sherr, 1984; Peterson and Fry, 1987) and are often used to determine composition of SPOM in estuaries 
(Cifuentes et al., 1988; Riera and Richard, 1997; Savoye et al., 2003; 2012; Modéran et al., 2012).

Due to potential overlaps of carbon stable isotope composition between different primary producers and the effects of decay processes on isotopic composition (Benner et al., 1987), stable isotopes of sulfur can be used to discriminate between the different food sources. Primary producers from continental areas are generally much more ${ }^{34} \mathrm{~S}$-depleted than primary producers from oceanic environments (Peterson et al., 1985; Peterson and Howarth, 1987; Thode, 1991). Stable isotope composition of nitrogen is generally used to determine the trophic levels of consumers (Minagawa and Wada, 1984; Vander Zanden and Rasmussen, 1999), but can also be an indicator of anthropogenic influence (i.e., release of wastewater from treatment plants) due to increase of $\delta^{15} \mathrm{~N}$ values with bacterial activity (McClelland and Valiela, 1998; Mooney and McClelland, 2012). The measurement of these three stable isotopes enables discrimination between the different pools of organic matter in order to determine its origin. The measurement of total organic carbon, chl $a$ and $\mathrm{C} / \mathrm{chl} a$ ratios along with these stable isotope ratios help determine the quantity and the quality of SPOM along a salinity gradient. The aim of this study was to determine how the different primary producers and inputs of allocthonous organic matter (i.e., from continental and marine origins) affect the composition, quantity and quality of SPOM, and to determine the evolution of these parameters in relation to changes in freshwater inflows. This study was conducted in the MissionAransas estuary, Texas, a semi-arid estuary that is vulnerable to changes in natural and anthropogenic changes in freshwater inflow.

\section{Material and methods}

\subsection{Study area}

The Mission-Aransas estuary is one of seven major estuarine systems located along the Texas coast (Fig. 1). It is a shallow, bar-built estuary composed of Aransas bay, the primary bay located closest to the Gulf of Mexico inlet, and Copano Bay, the secondary bay located closest to the two main rivers: the Mission and Aransas rivers. The Mission-Aransas estuary is $2 \mathrm{~m}$ deep on average, its 
surface is $463 \mathrm{~km}^{2}$ and its volume is $0.93 \mathrm{~km}^{3}$ (Armstrong, 1987). The Copano bay watershed is 4851 $\mathrm{km}^{2}$ (Borel et al., 2015); $49 \%$ of the freshwater comes from the Mission river and $15 \%$ from the Aransas river (Orlando et al., 1993).

The Mission-Aransas estuary is located in a sub-tropical humid climate. Rainfalls generally occur as brief and intense rain showers and as a result, freshwater inflows occur as episodic pulses. Rainfall, and consequently freshwater inflows, varies from year to year with alternating dry and wet periods (Evans and Morehead Palmer, 2012). From 2001-2010, freshwater inflows from both rivers ranged from 17 to 430 million $\mathrm{m}^{3} \mathrm{y}^{-1}$ (U.S. Geological Survey, 2012). On an annual basis, MissionAransas estuary is losing water due to higher evaporation (1513 $\left.\mathrm{mm} \mathrm{y}^{-1}\right)$ than precipitation $(886 \mathrm{~mm}$ $\left.\mathrm{y}^{-1}\right)$ (Armstrong, 1987). The estuary has low mixing efficiency $(<0.05)$ and long residence times $(\sim 360$ days, Solis and Powell, 1999). The salinity structure is driven by episodic freshwater pulses that depress salinities and then maintain low salinities for a prolonged period (Orlando et al., 1993).

The Mission-Aransas estuary hosts diverse primary producers and is fueled by different allocthonous sources i.e., continental organic matter from Mission and Aransas rivers in Copano bay, pelagic organic matter from the Gulf of Mexico in Aransas bay, organic matter from San Antonio bay transported southward across the Mesquite bay via the Intracoastal Waterway (Solis and Powell, 1999).

\subsection{Sampling stations}

Five stations were sampled along a salinity gradient in the Mission-Aransas estuary, with station 1 (St. 1) the closest to the Aransas river mouth and station 5 (St. 5) the closest to the Gulf of Mexico (Fig. 1). Three other stations were sampled to collect freshwater from the two main rivers (Mission river (MIS) and Aransas river (ARA), and sea water from the Gulf of Mexico (GoM). Freshwater inputs into Copano bay were determined by summing flows of Mission and Aransas rivers using data from USGS gauge stations (Fig. 1) located at Refugio (Mission river, Site ID: 08189500) and Skidmore (Aransas river, Site ID: 08189700) (U.S. Geological Survey, 2012). 


\subsection{Collection of water samples and sample processing}

At each station, three samples of surface water were collected on a monthly basis, from November 2010 (relatively high freshwater inflow) to August 2011 (relatively low freshwater inflow). All water samples were collected far enough from the shore to be representative of the river or bay water mass. Due to restricted access, it was impossible to sample water at the mouth of the Mission river.

Salinity was measured with an YSI 6920 multiprobe sonde, using practical salinity scale. Water samples were pre-filtered on a $250-\mu \mathrm{m}$ sieve to eliminate large zooplankton and detritus. For each water sample, SPOM was collected on four different filters (precombusted Whatman GF/F glass fiber filters, $0.7 \mu \mathrm{m}$ porosity) in order to measure stable isotope composition $\left(\delta^{13} \mathrm{C}, \delta^{15} \mathrm{~N}, \delta^{34} \mathrm{~S}\right)$ and $\mathrm{chl} a$ concentration. A volume ranging from 5 to $325 \mathrm{ml}$ was filtered under moderate vacuum; filters were then frozen at $-20^{\circ} \mathrm{C}$ and freeze-dried. Carbonates were removed from filters for $\delta^{13} \mathrm{C}$ and $\% \mathrm{C}$ analyses by contact with $\mathrm{HCl}$ fumes in a vacuum-enclosed system.

\subsection{Collection of primary producers for stable isotope analyses}

To determine the composition of SPOM, the main primary producers $\left(C_{3}\right.$ and $C_{4}$ salt marsh plants, seagrass, benthic microalgae) were sampled at different locations along the salinity gradient and during different seasons to examine possible spatio-temporal changes in isotopic composition. Vascular plants (leaves) and seagrass (leaves and roots) were collected, placed in plastic bags and stored in ice until return at the lab. They were then rinsed with tap water to remove detritus and sediment, frozen at $-20^{\circ} \mathrm{C}$, freeze-dried and ground to a fine and homogeneous powder using a ball mill.

Benthic microalgae were collected by scraping surface sediments in the field and then by extracting the microalgae in the laboratory following the method of Riera and Richard (1996), slightly modified by Herlory et al. (2007). Extracted samples were checked under a microscope for 
purity, then benthic microalgae were collected on three different filters (precombusted Whatman $\mathrm{GF} / \mathrm{F}$ glass fiber filters) in order to measure stable isotope composition $\left(\delta^{13} \mathrm{C}, \delta^{15} \mathrm{~N}, \delta^{34} \mathrm{~S}\right)$. Samples were frozen at $-20^{\circ} \mathrm{C}$ then freeze-dried.

\section{5 $\mathrm{Chl} a$ and stable isotope ratio measurements}

$\mathrm{Chl} a$ was extracted overnight from filters and read on a Turner Trilogy fluorometer (Turner Designs, Sunnyvale, USA) using a non-acidification technique (Welschmeyer, 1994). Detection limit of the fluorometer was $0.025 \mu \mathrm{g} \cdot \mathrm{L}^{-1}$ with a linear range of $0-300 \mu \mathrm{g} \cdot \mathrm{L}^{-1}$. Calibration was performed once a year using commercially available fluorometric chlorophyll calibration standards for chlorophyll a (Turner Designs).

Samples for stable isotope analyses and particulate organic carbon percentages were analyzed using an elemental analyzer (Flash EA 1112, Thermo Scientific, Milan, Italy) coupled with an isotope ratio mass spectrometer (Delta V Advantage with a Conflo IV interface, Thermo Scientific, Bremen, Germany) at the LIENSs stable isotope facility of the University of La Rochelle, France. Results are expressed in the $\delta$ notation as deviations from standards (Vienna Pee Dee Belemnite for $\delta^{13} \mathrm{C}, \mathrm{N}_{2}$ in air for $\delta^{15} \mathrm{~N}$ and Canyon Diablo Troilite for $\delta^{34} \mathrm{~S}$ ) following the formula: $\delta^{13} \mathrm{C}, \delta^{15} \mathrm{~N}$ or $\delta^{34} \mathrm{~S}=$ $\left[\left(R_{\text {sample }} / R_{\text {standard }}\right)-1\right] \times 10^{3}$, where $\mathrm{R}$ is ${ }^{13} \mathrm{C} /{ }^{12} \mathrm{C},{ }^{15} \mathrm{~N} /{ }^{14} \mathrm{~N}$ or ${ }^{34} \mathrm{~S} /{ }^{32} \mathrm{~S}$, respectively. Calibration was done using reference materials (USGS-24, IAEA-CH6, -600 for carbon; IAEA-N2, -NO-3, -600 for nitrogen; IAEA-S-1, -S-2 for sulfur). Analytical precision based on the analyses of acetanilide (Thermo Scientific) used as laboratory internal standard was $<0.06$ and $<0.1 \%$ for carbon and nitrogen, respectively. Analytical precision based on the analyses of sulfanilamide (Thermo Scientific) used as laboratory internal standard was $<0.15 \%$. Vanadium pentoxide was added in each SPOM sample as a catalyzer during sample combustion for sulfur elemental analysis.

\subsection{Data analyses and statistics}


Mean daily freshwater discharges were determined from September $1^{\text {st }}, 2010$ to September, $30^{\text {th }}$ 2011, using data from USGS gauge stations. Loads of POC into the Copano bay from the Aransas and the Mission rivers were computed by multiplying the mean daily freshwater discharge with the concentrations of POC $\left(\mu \mathrm{g} \cdot \mathrm{ml}^{-1}\right) . \mathrm{C} / \mathrm{chl} a$ ratios were computed using concentrations of particulate organic carbon $\left(\mu \mathrm{gl}^{-1}\right)$ from elemental analyses and of chlorophyll $a$ from fluorimetry measurements $\left(\mu \mathrm{g}^{-1}\right)$. Comparisons between stable isotope values of primary producers and SPOM samples were conducted using nonparametric procedures (i.e., Kruskal-Wallis rank sum test and Wilcoxon signed rank test), to determine any differences between locations, sampling dates and tissues (roots and leaves). Kruskal-Wallis tests were followed by multiple comparisons of means using the pgirmess package (Giraudoux, 2011) in R statistical software (R Development Core Team, 2010).

\section{Results and discussion}

\subsection{River discharges and hydrological features of the Mission-Aransas estuary in 2010-2011}

The year 2011 was a very dry year-the second driest (after 2008) of the past 10 years (Mooney and McClelland, 2012). Inputs of freshwater from the Aransas and Mission rivers to Copano bay were very low, with 21 million $\mathrm{m}^{3}$, compared to an average of 170 million $\mathrm{m}^{3} \mathrm{y}^{-1}$ over the past 10 years (U.S. Geological Survey, 2012). Freshwater inflows in the Mission-Aransas estuary decreased by more than 2 orders of magnitude from September $2010\left(2.3010^{6} \mathrm{~m}^{3} \mathrm{~d}^{-1}\right)$ to September 2011 $\left(8.0510^{3} \mathrm{~m}^{3} \mathrm{~d}^{-1}\right)$. A large pulse of freshwater occurred in September 2010-before the start of the experiment - with the highest input of $1.9210^{7} \mathrm{~m}^{3} \mathrm{~d}^{-1}$ on September $20^{\text {th }}$, leading to a strong salinity gradient in the estuary (Fig. 2 ; Mooney and McClelland, 2012; Bruesewitz et al., 2013). A minor pulse occurred in January 2011, with the highest input of $5.1510^{6} \mathrm{~m}^{3} \mathrm{~d}^{-1}$ on January $17^{\text {th }}, 2011$. During the January pulse (January $17^{\text {th }}$ and $18^{\text {th }}, 2011$ ), 96 and $4 \%$ of the freshwater inflow were issued from Mission and Aransas rivers, respectively.

Salinity increased along a gradient from Aransas river mouth (Station 1) to the Gulf of Mexico (GoM) (Fig. 2). This gradient was more evenly distributed along the length of the sampling transect 
in November 2010 (salinity from 5.2 to 24.3) than in August 2011 (salinity from 30.5 to 37.3) due to the overall increase of salinities in Copano and Aransas bays. The salinities of the river station ARA were close to zero throughout the study period although the salinities at the MIS river station rose to 5 by August 2011. Salinities measured at Station 5 and GoM were similar throughout the sampling period.

On average, evaporation largely exceeds precipitation in the Mission-Aransas estuary and south east winds generally predominates (Armstrong, 1987), which leads to a flow of water from Aransas bay into Copano bay, this flow being twice more than the volume of the freshwater issued from rivers (Johnson, 2009). Minor rain events in the Mission-Aransas watershed, like the one observed in January 2011, do not have any effect on the general hydrology of the bay, as evidenced by the general increase of salinity in the bay throughout the study period (Bruesewitz et al., 2013). Nevertheless, a slight decrease in salinity was observed at Station 4 in January 2011, indicating a potential flow of freshwater originating from San Antonio bay, which is connected to Aransas bay via the Intracoastal Waterway in Mesquite bay (Solis and Powell, 1999). As a result, from November 2010 to August 2011, a combination of low freshwater inflow, high evaporation and flow of saline water from Aransas bay into Copano bay led to a general increase in salinity throughout the estuary and compression of the salinity gradient, which was observed in November 2010. Thus, from November 2010 to August 2011, the Mission-Aransas estuary went from a system dominated by precipitation (i.e., positive estuary) to a system dominated by evaporation (i.e., negative estuary) (Pritchard, 1952; Montagna et al., 2013).

During the study period, particulate organic carbon (POC) concentrations ranged from 0.48 (December 10) to $2.8 \mathrm{\mu g} \mathrm{ml}^{-1}$ (August 11) in Aransas river and from 0.53 (March 11) to $2.12 \mathrm{\mu g} \mathrm{ml}^{-1}$ (August 11) in Mission river. POC concentration data in Mission river in November and December are missing due to technical issues. Except in January, computed load of POC into the Mission-Aransas estuary ranged from 334 to $939 \mathrm{~kg} \mathrm{month}^{-1}$ and from 15 to $1241 \mathrm{~kg} \mathrm{month}^{-1}$ for Aransas and Mission rivers, respectively. In January, POC load into the Mission-Aransas estuary was much higher, 
particularly for Mission river (13097 kg month ${ }^{-1}$ ) while Aransas river POC load was $3292 \mathrm{~kg} \mathrm{month}^{-1}$ (Fig. 2).

\subsection{Discrimination of the different benthic primary producers using stable isotopes}

Salt marsh plants had typical isotopic compositions for carbon as $C_{3}$ and $C_{4}$ plants were relatively

${ }^{13} \mathrm{C}$-depleted (-29.2 to $-26.8 \%$ ) and ${ }^{13} \mathrm{C}$-enriched (-15.5 to $-12.5 \%$ ), respectively (Table 1, Fig. 3). This disparity is mostly related to different enzymatic processes occurring during photosynthesis and differential utilization of $\mathrm{HCO}_{3}$ and $\mathrm{CO}_{2}$ (Smith and Epstein, 1971; Fry and Sherr, 1984; O'Leary et al., 1992). Seagrass material was the most ${ }^{13} \mathrm{C}$-enriched, with $\delta^{13} \mathrm{C}$ values ranging from -14.7 to $-10.7 \%$, typical for seagrasses (Hemminga and Mateo, 1996) and slightly higher than $\mathrm{C}_{4}$ vascular plants (Table 1, Fig. 3). Detrital matter from seagrass had a very low $\delta^{13} \mathrm{C}$ value at station $3\left(-18.1 \%\right.$ ) whereas $\delta^{13} \mathrm{C}$ value at station $4(-11.9 \%$ ) was in the range of fresh material. This large difference is probably related with the degradation process which leads to higher levels of lignin in detrital matter, which is ${ }^{13} \mathrm{C}$-depleted (Benner et al., 1987). As a result, degradation of seagrass may lead to a larger overlap between $\delta^{13} \mathrm{C}$ values of seagrass detritus and those of $\mathrm{C}_{4}$ salt marsh plants, either as fresh or as detritus. Benthic microalgae had a wide range of $\delta^{13} \mathrm{C}$ values, ranging from -21.7 to $-12.0 \%$, largely overlapping the ranges of values observed for seagrass and $\mathrm{C}_{4}$ vascular plants.

No pattern was observed for $\delta^{13} \mathrm{C}$ values of $\mathrm{C}_{3}$ and $\mathrm{C}_{4}$ plants between species, sampling dates and locations in the bay. Leaves and roots of seagrass were more ${ }^{13} \mathrm{C}$-enriched in downstream sections than in upstream sections of the Mission-Aransas estuary (Table 1, Kruskal-Wallis rank sum test, $\mathrm{p}$ values: Ruppia maritima: leaves: 0.013 , roots: 0.016 , Halodule wrigthii: leaves: 0.001 , roots: 0.004$)$. A similar pattern was observed for microphytobenthos (Kruskal-Wallis rank sum test, $p$-value: 0.035 ) and was clearly related to salinity: microphytobenthos had lower $\delta^{13} \mathrm{C}$ values (from -21.7 to $-16.4 \%$ ) at low salinities (Stations 1 and 3 in November, station 1 in March) than at high salinities (Fig. 4). This is probably due to the higher influence of dissolved inorganic carbonates from freshwater, which are ${ }^{13} \mathrm{C}$-depleted (Fry and Sherr, 1984). It is thus possible to discriminate these benthic algae from the 
other primary producers. The $\delta^{13} \mathrm{C}$ values of benthic algae collected in marine influenced environments, ranging from -14.2 to $-12.0 \%$, were in the range of those from the literature (Currin et al., 1995; Riera and Richard, 1996; Riera et al., 1999; Kharlamenko et al., 2008. Lebreton et al., 2011).

Seagrass, $C_{3}$ and $C_{4}$ vascular plants had a large range of $\delta^{15} \mathrm{~N}$ values, ranging from 2.0 to $9.2 \%$, from 4.5 to $10.0 \%$ and from -1.1 to $7.7 \%$, respectively. Very different $\delta^{15} \mathrm{~N}$ values were observed between the two samples of seagrass detrital matter, with values of $7.5 \%$ at station 3 and $1.8 \%$ at station 4 in November 2010. Halodule wrightii and Spartina alterniflora clearly had higher $\delta^{15} \mathrm{~N}$ values in upstream parts of the estuary than in downstream parts (Table 1, Wilcoxon signed rank test, p-values: Halodule wrigthii: leaves: 0.003 , roots: 0.004 , Spartina alterniflora: $<0.001) . \delta^{15} \mathrm{~N}$ values of microphytobenthos ranged from -0.6 to $5.3 \%$, with slightly higher $\delta^{15} \mathrm{~N}$ values at lower salinities.

Sulfur stable isotope composition of primary producers was highly variable, even at the species level (e.g., Spartina alterniflora, Borrichia frutescens, Ruppia maritima) (Table 1, Fig. 3). Among primary producers, $C_{3}$ vascular plants were the most enriched in ${ }^{34} \mathrm{~S}$, with $\delta^{34} \mathrm{~S}$ values ranging from 7.1 to $18.4 \%$. $C_{4}$ vascular plants were less enriched in ${ }^{34} \mathrm{~S}$, with values ranging from -5.8 to $7.1 \%$. However, these values were higher than those previously observed during other studies (Peterson et al., 1986; Peterson and Howarth, 1987; Sullivan and Moncreiff, 1990; Currin et al., 1995). This large range of $\delta^{34} S$ values is linked with differential assimilation of sediment sulfides, which are ${ }^{34} \mathrm{~S}$ depleted, and of sulfates, which are ${ }^{34}$ S-enriched, depending on seasonal and spatial conditions (Carlson and Forrest, 1982; Fry et al., 1982; Currin et al., 1995; Stribling et al., 1998). The much higher $\delta^{34} S$ values measured on $C_{3}$ plants in comparison with those of $C_{4}$ plants indicate that $C_{3}$ plants assimilate sulfates originating from precipitation (0 to 15\%) and seawater (21\%o) (Peterson et al., 1986; Peterson and Howarth, 1987; Krouse et al., 1991; Connolly et al., 2004). No clear pattern was observed between $\delta^{34} S$ values and salinity, location or sampling time for $C_{3}$ and $C_{4}$ vascular plants. 
Microphytobenthos had intermediate $\delta^{34} S$ values, going from 4.1 to $11.8 \%$, in the range of those

reviewed by Currin et al. (1995). No relation was observed between $\delta^{34} S$ values of microphytobenthos and salinities, in contrast to the pattern observed in carbon isotopic composition, as these samples were collected at salinities $(>5.2)$ for which isotopic composition of sulfates is already relatively high. In the Mississippi river estuary, Fry and Chumcall (2011) highlighted that the stable isotope composition of sulfates mostly varies at very low salinities $(<0.6)$ and then remains relatively stable $(21 \%)$, close to the isotopic composition of sulfates in seawater (Nriagu et al., 1991).

Seagrass also had a wide range of $\delta^{34} \mathrm{~S}$ values, with roots generally much more ${ }^{34} \mathrm{~S}$-depleted than leaves: -11.1 to $7.8 \%$ vs. -1.5 to $6.1 \%$, respectively. The differences observed between leaves and roots are probably related with a differential uptake of sulfur by these two tissues. Roots mostly use sediment sulfur which contains high quantities of sulfides resulting from anaerobic bacterial activity, and are generally very ${ }^{34} \mathrm{~S}$-depleted $(-10$ to $-35 \%$ ), whereas leaves use dissolved sulfates from the water column (21\%o) (Fry et al., 1982; Nriagu et al., 1991; Moncreiff and Sullivan, 2001). As a result, there is good discrimination between seagrass roots and benthic algae or $C_{4}$ plants thanks to $\delta^{34} S$ values. However, the large range of $\delta^{34} S$ values observed on seagrass leaves and $C_{4}$ plants do not allow for discrimination between these two primary producers. The large variations described for $\delta^{34} \mathrm{~S}$ values, depending on species, tissues, locations and seasons (Fry et al., 1982; Moncreiff and Sullivan, 2001; Oakes and Connolly, 2004; Belicka et al., 2012), signify that information issued from sulfur stable isotope composition should be used with caution in large scale ecosystem studies (Connolly et al., 2004).

As a result, $C_{3}$ vascular plants are very well differentiated from all other primary producers and some microphytobenthos samples are clearly separated from seagrass and $C_{4}$ plants. $\delta^{34} S$ measurements allow for good discrimination between microphytobenthos and seagrass detritus (Table 1, Fig. 3). The combination of three different stable isotope markers $\left(\delta^{13} \mathrm{C}, \delta^{15} \mathrm{~N}\right.$ and $\left.\delta^{34} \mathrm{~S}\right)$ thus allowed the discrimination of three different groups of benthic primary producers from the Mission- 
Aransas estuary: 1) $C_{3}$ salt marsh plants, 2) benthic microalgae, and 3) $C_{4}$ salt marsh plants and seagrass (Peterson and Howarth, 1987; Sullivan and Moncreiff, 1990; Currin et al., 1995; Connolly et al., 2004).

\subsection{Origin and quality of allocthonous inputs from the Aransas and Mission rivers and from the Gulf of Mexico}

The Mission-Aransas estuary receives inputs of organic matter from its different watersheds, mostly the Aransas and Mission rivers, which drain the highest quantity of freshwater into this estuary. Some allocthonous inputs may also originate from the Gulf of Mexico, via the pass at Port Aransas, due to movements of water masses due to tides, winds and evaporation of water into Aransas bay (Solis and Powell, 1999). During this survey, the origin and quality of allocthonous inputs of organic matter may have been influenced by two patterns: 1) From November 2010 to August 2011, a general decrease of freshwater inflow, and 2) A minor rain event in January 2011.

$\delta^{13} \mathrm{C}, \delta^{15} \mathrm{~N}$ and $\delta^{34} \mathrm{~S}$ values of SPOM at GoM station were stable throughout the year, ranging from to -23.2 (January 2011) to $-20.8 \%$ (April 2011), from 6.5 (December 2010) to 8.6\%o (May 2010) and from 16.5 (May 2011) to 18.5\%o (July and January 2011), respectively (Fig. 5, Table 2, Appendix A). Chl $a$ concentrations were relatively low all year long, with values ranging from $2.1 \pm 0.2$ (May 2011) to $6.7 \pm 0.3 \mu \mathrm{g} . \mathrm{I}^{-1}$ (February 2011) (Fig. 6). Combined to the low C/chl $a$ values (ranging from 154 to 484, Fig. 6), indicating that this organic matter was fresh (Cifuentes et al., 1988; Savoye et al., 2012), stable isotope values indicated that the composition of organic matter from the Gulf of Mexico varied little all year long, being mostly composed of fresh marine phytoplankton. Seawater SPOM $\delta^{13} \mathrm{C}$ values range indeed typically from -18 to $-24 \%$ (Fry and Sherr, 1984, Riera et al., 2000) and $\delta^{34} \mathrm{~S}$ values are close to $21 \%$ (Fry et al., 1982; Nriagu et al., 1991).

Composition of SPOM from Aransas and Mission rivers was generally stable and much more ${ }^{13} \mathrm{C}$ depleted (i.e., ranging from -35.5 to $-27.7 \%$ ) than SPOM at GoM station, except in January 2011, when $\delta^{13} \mathrm{C}$ values of SPOM from Aransas (-24.0\%) and Mission rivers (-25.1\%o) were similar to that 
from GoM (Fig. 5, Tables 2 and 3, Appendix A). $\delta^{15} \mathrm{~N}$ values of SPOM from rivers were much more variable (Table 2, Fig. 5). SPOM from Mission river typically had $\delta^{15} \mathrm{~N}$ values similar to those observed in the Mission-Aransas estuary, but low $\delta^{15} \mathrm{~N}$ values in winter (3.6\% in January 2011) (Fig. 5, Table 3). $\delta^{15} \mathrm{~N}$ values of SPOM from Aransas river were the most variable, with a large enrichment in ${ }^{15} \mathrm{~N}$ between January and February $2011\left(17.5 \%\right.$ ) and then a gradual decrease in ${ }^{15} \mathrm{~N}$, until reaching $\delta^{15} \mathrm{~N}$ values observed in the Mission-Aransas estuary in July 2011 (4.8\%) (Fig. 5). SPOM sulfur stable isotope composition was generally relatively depleted in the Aransas and Mission rivers (from 3.3 to 9.6\%o), except in November and December 2010 in the Mission river, when $\delta^{34} S$ values of SPOM were slightly higher (12.1 and 10.7\%o, respectively) (Fig. 5).

Due to sampling complications, $\mathrm{chl} a$ concentrations and $\mathrm{C} / \mathrm{chl} a$ ratios are not available at station MIS in November and in December 2010. From November 2010 to August 2011, chl $a$ concentrations were highly variable in Aransas and Mission rivers, ranging from 0.7 (MIS, January) to $43.2 \mu \mathrm{g} . \mathrm{I}^{-1}$ (ARA, February) (Fig. 6, Table 2). Chl a concentrations were particularly high in Aransas river in February and March. From May to August, chl a concentrations were frequently higher in Aransas and Mission rivers than at station 5 or GoM (Table 3). C/chl $a$ ratios were high in January in Mission (1638) and Aransas (1385) rivers (Fig. 6).

Except in January and February 2011, the composition and quality of organic matter issued from the Aransas and Mission rivers was pretty constant. The combination of $\mathrm{C} / \mathrm{chl} a$ ratios and of $\delta^{13} \mathrm{C}$ and $\delta^{34} \mathrm{~S}$ values demonstrates indeed that the organic matter from the Aransas and Mission rivers was mostly composed of freshwater phytoplankton. The $\delta^{13} \mathrm{C}$ values of SPOM, lower than $-27 \%$, are typical of freshwater phytoplankton (Fry and Sherr, 1984; Cifuentes et al., 1988; Boutton, 1991) and $\delta^{34} \mathrm{~S}$ values (from 3.3 to $12.2 \%$ ) indicated that these primary producers were relying on sulfates from riverine waters (Nriagu and Coker, 1978; Chukhrov et al., 1980; Nriagu et al., 1991). Carbon to chl $a$ ratios, with most of the values lower than 200 , confirmed that SPOM was mostly composed of fresh material (Cifuentes et al., 1988; Savoye et al., 2012). Blooms of freshwater phytoplankton were observed in June and July in the Mission river and in July and August in the Aransas river, when Chl a 
concentrations were high $\left(>15 \mu \mathrm{g} \mathrm{I}^{-1}\right)$ and $\mathrm{C} / \mathrm{chl} a$ ratios were lower than 100 , demonstrating that SPOM was only composed of fresh phytoplankton.

In January 2011, a minor rain event strongly affected the composition of the riverine SPOM. Much higher $\mathrm{C} / \mathrm{chl} a$ values ( $>1300$ ) in January demonstrated that SPOM was mostly composed by refractory material (i.e., detrital matter) (Cifuentes et al., 1988; Savoye et al., 2012). Higher $\delta^{13} C$ values (-24.0 and $-25.1 \%$ in Aransas and Mission rivers, respectively) indicated a higher influence of $\mathrm{C}_{4}$ plant material in the riverine SPOM composition than during previous months. The MissionAransas estuary watershed has a high number of $\mathrm{C}_{4}$ primary producers, since it is composed of $30 \%$ of grassland (Mooney and McClelland, 2012), with $68 \%$ of the grasses being $\mathrm{C}_{4}$ plants (Teeri and Stowe, 1976). Moreover, main crops in the Mission-Aransas estuary, particularly in the Aransas watershed are $\mathrm{C}_{4}$ plants (i.e., sorghum and corn) (Mooney and McClelland, 2012). The ${ }^{13} \mathrm{C}$ enrichment indicates rainfall drained high quantities of detrital matter from continental origin within the watershed into the rivers. In February 2011, the peak of $\delta^{15} \mathrm{~N}$ values in the Aransas river is very likely related with the release of highly ${ }^{15} \mathrm{~N}$-enriched nitrogen originating from wastewater treatment plants (McClelland and Valiela, 1998), probably due to the overwhelming of their treatment capacities during the January rain event (Mooney and McClelland, 2012). This higher release of enriched nitrogen only occurred in the Aransas river, which is subject to a much higher discharge of wastewater than the Mission river (Mooney and McClelland, 2012). The release of enriched nitrogen, in higher quantities than during base flow (Bruesewitz et al., 2013), stimulated the production of freshwater phytoplankton in February and March as illustrated by the higher chl $a$ concentrations. The gradual decrease of $\delta^{15} \mathrm{~N}$ values after this event indicates that there was a slow dilution of this enriched nitrogen during the following months, due to the very low flows of fresh water. This highlights that the different management and land use land cover of these two riversone with numerous discharge points of wastewater and dominated by a watershed dominated by agricultural fields, and the other one with low wastewater release and a watershed dominated by shrub-have a different effect on the riverine SPOM composition. Rain events also have a clear 
effect on the composition of riverine organic matter: In periods of normal flow, riverine waters contain low concentrations of high quality SPOM whereas they contain high concentrations of low quality SPOM during rain events.

As evidenced by the decrease in salinity observed at St. 4 in January, there are also exchanges of organic matter between Copano and Aransas bays, San Antonio bay and Corpus Christi bay through the Intracoastal Waterway. Unfortunately, our sampling design did not take into account these potential flows of organic matter, and it is therefore not possible to determine the composition and the quantity of organic matter carried by the Intracoastal Waterway.

\subsection{Autochthonous phytoplankton dominates SPOM composition during droughts}

$\delta^{13} \mathrm{C}$ values of SPOM in the Mission Aransas estuary (i.e., stations 1 to 5) ranged from -26.9 (January 2011, Station 2) to $-20.8 \%$ (April 2011, station 4) and were relatively stable throughout the year. No clear temporal pattern was observed even though some $\delta^{13} \mathrm{C}$ values of SPOM were occasionally significantly lower during some fall and winter months than during some spring and summer months (Fig. 5, Table 2). No clear spatial difference was observed between $\delta^{13} \mathrm{C}$ values in the estuary, except in January 2011, when SPOM at station 2 was significantly more depleted than at station 5 (Fig. 5, Table 3). $\delta^{15} \mathrm{~N}$ values of SPOM at stations 1 to 5 were also relatively stable and similar between stations, ranging from 4.7 (August 2011, station 1) to 8.8\%o (November 2010, station 2) (Fig. 5, Tables 2 and 3). $\delta^{34} \mathrm{~S}$ values of SPOM were rather relatively stable and similar throughout the year from stations 1 to 5, ranging from 11.9 (January 2011, station 1) to 20.0\%o (April 2011, station 4) (Fig. 5, Tables 2 and 3). Chl $a$ concentrations were less variable in the MissionAransas estuary (St. 1 to St. 5) than in the rivers, ranging from 0.7 (July 2011, station 5) to $20.1 \mu \mathrm{g} . \mathrm{I}^{-1}$ (April 2011, station 1). Two peaks of chl $a$ concentrations in November and April were observed at station 1 (Fig. 6, Table 2). C/chl a ratios observed in the Mission-Aransas estuary ranged from 114 (January 2011, station 1) to 803 (February 2011, station 3) (Fig. 6). 
As a result, the composition of SPOM was relatively constant in the Mission-Aransas estuary

during the survey, even if some slight spatio-temporal differences were observed. On a yearly basis, $\delta^{13} \mathrm{C}$ and $\delta^{34} \mathrm{~S}$ values of estuarine SPOM were very different from the carbon and sulfur isotopic compositions of benthic primary producers (Fig. 3), demonstrating that these primary producers had a negligible influence on the composition of estuarine SPOM, either as fresh (i.e., resuspended benthic microalgae) or as detrital matter (i.e., seagrass, $C_{3}$ or $C_{4}$ plant) (Qian et al., 1996). The carbon and sulfur isotopic composition of estuarine SPOM demonstrated that this organic matter was, all year long, mostly composed by locally produced phytoplankton. This indicates minimal benthicpelagic coupling in the Mission-Aransas estuary, which is relatively surprising because windy conditions can increase turbidity (Beseres Pollack et al., 2012), allowing for resuspension of sediment organic matter. Organic matter of benthic origin is thus either exported as large particles (e.g., seagrass leaves) or buried in the sediment.

The carbon and sulfur isotopic compositions of estuarine SPOM were very different from those of riverine SPOM (Fig. 3). From March to July, there was also no influence of the highly ${ }^{15} \mathrm{~N}$-enriched SPOM discharge from the Aransas river in Copano bay (Fig. 5). This indicates that organic matter from rivers had a very low influence on the general functioning of the Mission-Aransas estuary during droughts, probably because inputs of riverine SPOM were in very low quantity, due to the very low freshwater inflows, whereas autochthonous phytoplanktonic production is high in the Mission-Aransas estuary, like in other Texas estuaries (Pennock et al., 1999).

\subsection{Effect of freshwater inflow into composition of SPOM}

A slight influence of riverine SPOM was occasionally and very locally observed during the minor rain event - which occurred in January - at stations close to the Aransas and Mission river mouths and at station 4, probably due to an influence of riverine organic matter from San Antonio bay drained through the Intracoastal Waterway. We used data from our survey (i.e. during drought) and from the survey carried out by Mooney and McClelland (2012) (i.e. during drought and flood) for 
Copano bay, the secondary bay of the estuary, to determine how freshwater inflows affect the composition and the quality of the SPOM. We determined that an exponential relationship exists between SPOM $\delta^{13} \mathrm{C}$ values and monthly freshwater inflows (moving average of the present and the two previous monthly freshwater inflows) from the Aransas and Mission rivers (Fig. 7).

We then considered two scenarios: droughts and rain events. In our study, we observed that the riverine SPOM is dominated by freshwater phytoplankton $\left(\delta^{13} \mathrm{C}=-31.4 \%\right)$ during droughts and by detrital matter of $C_{3}$-plants $\left(\delta^{13} \mathrm{C}=-24.7 \%\right.$ ) during rain events. We considered that the SPOM $\delta^{13} \mathrm{C}$ value in Copano bay without any freshwater inflow (i.e., autochthonous production only) would be equal to the $\delta^{13} \mathrm{C}$ value of SPOM from the Gulf of Mexico $(-22.1 \%$ ). For both scenarios, we computed the average $\delta^{13} \mathrm{C}$ value which would result from an equal mixture of SPOM from rivers and SPOM from autochthonous production. We then determined the threshold of monthly freshwater inflow between a system more influenced by riverine inputs vs. a system more influenced by autochthonous production. In other words, a monthly freshwater inflow higher than the threshold indicates that SPOM in the secondary bay is dominated by riverine inputs whereas a monthly freshwater inflow lower than the threshold indicates that SPOM in the secondary bay is dominated by autochthonous production.

The scenario based on drought conditions gave an inflow threshold of 6.8 million $\mathrm{m}^{3} \mathrm{month}^{-1}$. This inflow of freshwater is much higher than the base flow conditions, and corresponds to a very high discharge of freshwater, which only occurs during large rain events. As a result, this computation demonstrates that the required inflow of freshwater for a significant effect of riverine inputs into the SPOM composition of Copano bay corresponds to a large rise in river level (i.e., rain event, which does not correspond to this scenario anymore). This means that riverine inputs during droughts (composed by riverine fresh phytoplankton) cannot have any major influence in the SPOM composition of this secondary bay. As a result, during droughts, SPOM will always be dominated by locally produced phytoplankton. 
The scenario based on rain event conditions gave an inflow threshold of $910,000 \mathrm{~m}^{3}$ month $^{-1}$. Consequently, when freshwater inflow is higher than this threshold the SPOM in Copano bay shifts gradually from fresh autochthonous phytoplankton to highly degraded terrestrial material. Indeed, the very high $\mathrm{C} / \mathrm{chl} a$ ratios of riverine SPOM drained during rain events indicate that this material is highly degraded, and is probably of very low nutritive quality for potential consumers (e.g., suspension feeders) (Ittekkot, 1988). The quality of the SPOM thus decreases into Copano bay, which may affect its fate and very likely the functioning of the estuarine food web. In 2007, the large floods, which occurred in the Mission Aransas estuary watershed affected oyster filtration rates, due to low salinities (Beseres Pollack et al., 2011). We suggest that the poor quality of the organic matter provided to the oysters during rain events may also affect the filtration rates, and thus the growth of oysters.

Minor rain events may also affect local production of phytoplankton, as demonstrated by the peak of chlorophyll $a$ in January (Pennock et al., 1999; Mooney and McClelland, 2012). Phytoplankton production increase due to a higher discharge of nutrients and remineralization of terrestrial organic matter drained into the estuary (Mooney and McClelland, 2012; Bruesewitz et al., 2013). As a result, even if pulses of freshwater do not drain SPOM of sufficient nutritional quality for its assimilation by consumers, the release of nutrients allows for local increase of autochthonous phytoplankton production, which may locally support the functioning of food webs.

\section{Conclusion: Functioning of a South Texas estuary}

Overall, autochthonous phytoplankton was the dominant component of SPOM in the MissionAransas estuary, during droughts but also during the minor rain event. Benthic organic matter did not influence SPOM composition, either as fresh material or as detritus. The influence of riverine inputs was very low and restricted to areas close to river mouths, due to the high residence time in the Mission-Aransas estuary (Solis and Powell, 1999). 
A comparison of the functioning of the Mission-Aransas estuary with the Sabine-Neches estuary (i.e., neutral vs. highly positive estuary) reveals that freshwater inflow clearly affects composition of SPOM in these two estuaries. On a global basis, the Sabine-Neches receives high loads of low quality organic matter which are relatively quickly flushed outside of the system due to the large freshwater inflow whereas the biomass of autochthonous phytoplankton is low due to the high turbidity (Cifuentes et al, 1999). The general functioning of the Mission-Aransas estuary is different, with high phytoplanktonic production and very low inputs of refractory continental organic matter. The Mission-Aransas estuary is thus dominated by autochthonous production. Because of predicted global change, which will result in a drier climate along Gulf of Mexico coastline (Nielsen-Gammon, 2011 ; IPCC, 2013) and the increasing demand for fresh water for human activities (Montagna et al., 2002), it is therefore probable that general functioning of Texas estuaries will shift towards systems less based on allocthonous inputs of SPOM and much more influenced by SPOM from autochthonous pelagic production. These changes in organic matter quality will probably have a large effect on the functioning of food webs in Texas estuaries.

A potential shift from estuaries where SPOM is dominated by poor quality allocthonous inputs to estuaries dominated by high quality autochthonous production would also lead to issues related with nutrients, due to the importance of nutrients for phytoplankton production. A better understanding of the relationships between nutrient inputs and freshwater inflows, such as that carried out by Mooney and McClelland (2012) in Copano bay, may be necessary at a much larger regional scale. A monitoring of these changes along the Texas coastline will require a combination of studies based on SPOM composition and nutrient loads along the coastal shoreline.

\section{Acknowledgments}

This study was partially funded thanks to a postdoctoral research grant from the Conseil Général of Charente Maritime in France. B. Lebreton is grateful to R. Kalke, M. Besonen, S. Arismendez, D. Yoskowitz, P. Richard and G. Blanchard for their very helpful advices and their support. Authors 
thank E. Hill and K. Withers for their help in benthic algae identification and G. Wise who allowed the collection of water samples on his property. B. Lebreton also thanks E. Morgan, A. Lord, C. Santos, L. Hutchison, K. Welder, B. Paudel, L. Hyde, D. Mangold, E. Chalkley, C. Taylor, M. Proffitt, E. Buschfort, C. Hampton, C. Carollo, M. Barajas for their invaluable help during collection and preparation of samples, and G. Sutton, L. Eckert and A. Knight for their support in administrative tasks. Authors also thank the two reviewers who helped to improve the manuscript thanks to their comments.

\section{References}

Armstrong, N.A., 1987. The Ecology of Open-bay Bottoms of Texas: a Community Profile. U. S. Fish and Wildlife Service Biological Report 85, Austin, USA, 104 pp.

Beck, M.W., Heck Jr., K.L. , Able, K.W., Childers, D.L., Eggleston, D.B., Gillanders, B.M., Halpern, B., Hays, C.G., Hoshino, K., Minello, T.J., Orth, R.J., Sheridan, P.F., Weinstein, M.P., 2001. The identification, conservation, and management of estuarine and marine nurseries for fish and invertebrates. Bioscience 51, 633-641.

Beck, M.W., Brumbaugh, R.D., Airoldi, L., Carranza, A., Coen, L.D., Crawford, C., Defeo, O., Edgar, G.J., Hancock, B., Kay, M.C., Lenihan, H.S., Luckenbach, M.W., Toropova, C.L., Zhang, G., Guo, X., 2011. Oyster reefs at risk and recommendations for conservation, restoration, and management. Bioscience 61, 107-116.

Belicka, L.L., Burkholder, D., Fourqurean, J.W., Heithaus, M.R., Macko, S.A., Jaffé, R., 2012. Stable isotope and fatty acid biomarkers of seagrass, epiphytic, and algal organic matter to consumers in a pristine seagrass ecosystem. Marine and freshwater research 63, 10851097.

Benner, R., Fogel, M.L., Sprague, E.K., Hodson, R.E., 1987. Depletion of ${ }^{13} \mathrm{C}$ in lignin and its implication for stable carbon isotope studies. Nature 329, 708-710. 
Beseres Pollack, J., Cleveland, A., Palmer, T.A., Reisinger, A.S., Montagna, P.A., 2012. A Restoration suitability index model for the eastern oyster (Crassostrea virginica) in the Mission-Aransas estuary, TX, USA. PLoS ONE 7, e40839.

Beseres Pollack, J., Kim, H.-C., Morgan, E.K., Montagna, P.A., 2011. Role of flood disturbance in natural oyster (Crassostrea virginica) population maintenance in an estuary in South Texas, USA. Estuaries and Coasts 34, 187-197.

Borel, K., Karthikeyan, R., Berthold, T.A., Wagner, K., 2015. Estimating E. coli and Enterococcus loads in a coastal Texas watershed. Texas Water Journal 6, 33-44.

Boutton, T.W., 1991. Stable carbon isotope ratios of natural materials: II. Atmospheric, terrestrial, marine, and freshwater environments. In: Coleman, D.C., Fry, B., (Eds.), Carbon isotope techniques. Academic press, San Diego, pp. 173-185.

Bruesewitz, D.A., Gardner, W.S., Mooney, R.F., Pollard, L., Buskey, E.J., 2013. Estuarine ecosystem function response to flood and drought in a shallow, semiarid estuary: Nitrogen cycling and ecosystem metabolism. Limnology and Oceanography 58, 2293-2309.

Carlson Jr., P.R., Forrest, J., 1982. Uptake of dissolved sulphide by Spartina alterniflora. Evidence from natural sulphur isotope abundance ratios. Science 216, 633-635.

Cifuentes, L.A., Sharp, J.H., Fogel, M.L., 1988. Stable carbon and nitrogen isotope biogeochemistry in the Delaware estuary. Limnology and Oceanography 33, 1102-1115.

Cifuentes, L.A., Coffin, R.B., Morin, J., Bianchi, T.S., Eldridge, P.M., 1999. Particulate organic matter in Gulf of Mexico estuaries - Implications for net heterotrophy. In: Bianchi, T.S., Pennock, J.R., Twilley, R.R. (Eds.), Biogeochemistry of Gulf of Mexico estuaries. John Wiley \& Sons, New York, pp. 239-267.

Chukhrov, F.V., Ermilova, L.P., Churikov, V.S., Nosik, L.P., 1980. The isotopic composition of plant sulfur. Organic Geochemistry 2, 69-75.

Connolly, R.M., Guest, M.A., Melville, A.J., Oakes, J.M., 2004. Sulfur stable isotopes separate producers in marine food-web analysis. Oecologia 138, 161-167. 
Currin, C.A., Newell, S.Y., Paerl, H.W., 1995. The role of standing dead Spartina alterniflora and benthic microalgae in salt marsh food webs: considerations based on multiple stable isotope analysis. Marine Ecology Progress Series 121, 99-116.

Dunton, K.H., Hardegree, B., Whitledge, T.E., 2001. Response of estuarine marsh vegetation to interannual variations in precipitation. Estuaries 24, 851-861.

Evans, A., Morehead Palmer, S., 2012. Hydrography and oceanography. In: Evans, A., Madden, K., Morehead Palmer, S., The Ecology and Sociology of the Mission-Aransas Estuary. An Estuarine and Watershed Profile. University of Texas Marine Science Institute, Port Aransas, pp. 19-23.

Fry, B., Scalan, R.S., Winters, J.K., Parker, P.L., 1982. Sulphur uptake by salt grasses, mangroves, and seagrasses in anaerobic sediments. Geochimica et Cosmochimica Acta 46, 1121-1124.

Fry, B., Sherr, E.B., 1984. $\delta^{13} \mathrm{C}$ measurements as indicators of carbon flow in marine and freshwater ecosystems. Contributions in Marine Science 27, 13-47.

Fry, B., Chumcall, M.M., 2011. Sulfur stable isotope indicators of residency in estuarine fish. Limnology and Oceanography 56, 1563-1576.

Giraudoux, P., 2011. pgirmess: data analysis in ecology. R package version 1.5.0. http://cran.rproject.org/web/packages/pgirmess/index.html

Grabowski, J.H., Brumbaugh, R.D., Conrad, R.F., Keeler, A.G., Opaluch, J.J., Peterson, C.H., Piehler, M.F., Powers, S.P., Smyth, A.R., 2012. Economic valuation of ecosystem services provided by oyster reefs. Bioscience 62, 900-909.

Hedges, J.I., Keil, R.G., Benner, R., 1997. What happens to terrestrial organic matter in the coean? Organic Geochemistry 27, 195-212.

Hemminga, M.A., Mateo, M.A., 1996. Stable carbon isotopes in seagrasses: variability in ratios and use in ecological studies. Marine Ecology Progress Series 140, 285-298.

Herlory, O., Richard, P., Blanchard, G.F., 2007. Methodology of light response curves: application of chlorophyll fluorescence to microphytobenthic biofilms. Marine Biology 153, 91-101. 
IPPC, 2013. Climate change 2013: The physical science basis. Contribution of working group I to the fifth assessment report of the intergovernmental panel on climate change. Stocker, T. F., Qin, D., Plattner, G.-K., Tignor, M., Allen, S. K., Boschung, J., Nauels, A., Xia, Y., Bex, V., Midgley, P. M. (Eds.). Cambridge University Press, Cambridge, 1535 pp.

Ittekkot, V., 1988. Global trends in the nature of organic matter in river suspensions. Nature 332, 436-438.

Johnson, S.L., 2009. A general method for modeling coastal water pollutant loadings. Ph.D. Thesis, University of Texas at Austin, USA, unpublished.

Kharlamenko, V.I., Kiyashko, S.I., Rodkina, S.A., Imbs, A.B., 2008. Determination of food sources of marine invertebrates from a subtidal sand community using analyses of fatty acids and stable isotopes. Russian Journal of Marine Biology 34, 101-109.

Krouse, H.R., Stewart, J.W.B., Grinenko, V.A., 1991. Pedosphere and biosphere. In: Krouse, H.R., Grinenko, V. A. (Eds.), Stable Isotopes in the Assessment of Natural and Anthropogenic Sulphur in the Environment. John Wiley \& Sons, Chichester, pp. 267-306.

Lebreton, B., Richard, P., Galois, R., Radenac, G., Pfléger, C., Guillou, G., Mornet, F., Blanchard, G.F., 2011. Trophic importance of diatoms in an intertidal Zostera noltii seagrass bed: Evidence from stable isotope and fatty acid analyses. Estuarine, Coastal and Shelf Science 92, 140153.

Longley, W.L., 1994. Freshwater inflows to Texas bays and estuaries: ecological relationships and methods for determination of needs. Texas water development board and Texas parks and wildlife department, Austin, $386 \mathrm{pp}$.

Longley, W.L., 1995. Estuaries. In: North, G., Schmandt, J., Clarkson, J. (Eds.), The Impact of Global Warming on Texas: a Report of the Task Force on Climate. University of Texas Press, Austin, pp. 88-118.

McClelland, J.W., Valiela, I., 1998. Linking nitrogen in estuarine producers to land-derived sources. Limnology and Oceanography 43, 577-585. 
McLusky, D.S., 1989. The Estuarine Ecosystem. Chapman and Hall, New York, 256 pp.

Mooney, R.F., McClelland, J., 2012. Watershed export events and ecosystem responses in the Mission-Aransas National Estuarine Research Reserve, South Texas. Estuaries and Coasts $35,1468-1485$.

Minagawa, M., Wada, E., 1984. Stepwise enrichment of ${ }^{15} \mathrm{~N}$ along food chains: further evidence and the relation between $\delta^{15} \mathrm{~N}$ and animal age. Geochimica et Cosmochimica Acta 48, 11351140.

Modéran, J., David, V., Bouvais, P., Richard, P., Fichet, D., 2012. Organic matter exploitation in a highly turbid environment: Planktonic food web in the Charente estuary, France. Estuarine, Coastal and Shelf Science 98, 126-137.

Moncreiff, C.A., Sullivan, M.J., 2001. Trophic importance of epiphytic algae in subtropical seagrass beds: evidence from multiple stable isotope analyses. Marine Ecology Progress Series 215, 93-106.

Montagna, P.A., Alber, M., Doering, P., Connor, M.S., 2002. Freshwater inflow: science, policy, management. Estuaries 25, 1243-1245.

Montagna, P.A., Palmer, T.A., Beseres Pollack, J., 2013. Conceptual model of estuary ecosystems. In: Montagna, P. A., Palmer, T. A., Beseres Pollack, J. (Eds.), Hydrological Changes and Estuarine Dynamics. Springer, New York, pp. 5-21.

Nielsen-Gammon, J., 2011. The changing climate of Texas. In: Schmandt, J., Clarkson, J., North, G.R. (Eds.), The Impact of Global Warming on Texas. University of Texas Press, Austin, pp 24-56.

Nriagu, J.O., Coker, R.D., 1978. Isotopic composition of sulphur in atmospheric precipitation around Sudbury, Ontario. Nature 278, 883-885.

Nriagu, J.O., Rees, C.E., Mekhtiyeva, V.L., Yu, L., Fritz, P., Drimmie, R.J., Pankina, R.G., Robinson, R.W., Krouse, H.R., 1991. Hydrosphere. In: Krouse, H.R., Grinenko, V. A (Eds.), Stable Isotopes in the Assessment of Natural and Anthropogenic Sulphur in the Environment. John Wiley \& Sons, Chichester, pp. 177-265. 
O'Leary, M.H., Madhavan, S., Paneth, P., 1992. Physical and chemical basis of carbon isotope fractionation in plants. Plant, Cell \& Environment 15, 1099-1104.

Oakes, J.M., Connolly, R., 2004. Causes of sulfur isotope variability in the seagrass, Zostera capricorni. Journal of Experimental Marine Biology and Ecology 302, 153-164.

Orlando Jr., S.P., Rozas, L.P., Ward, G.H., Klein, C.J., 1993. Salinity Characteristics of Gulf of Mexico Estuaries. National Oceanic and Atmospheric Administration, Office of Ocean Resources Conservation and Assessment, Silver Spring, 209 pp.

Pennock, J.R., Boyer, J.N., Herrera-Silveira, J.A., Iverson, R.L., Whitledge, T.E., Mortazavi, B., Comin, F.A., 1999. Nutrient behavior and phytoplankton production in Gulf of Mexico estuaries. In: Bianchi, T.S., Pennock, J.R., Twilley, R.R. (Eds.), Biogeochemistry of Gulf of Mexico Estuaries. John Wiley \& Sons, New York, pp. 109-162.

Peterson, B.J., Howarth, R.W., Garritt, R.H., 1985. Multiple stable isotopes used to trace the flow of organic matter in estuarine food webs. Science 227, 1361-1363.

Peterson, B.J., Howarth, R.W., Garritt, R.H., 1986. Sulfur and carbon isotopes as tracers of salt-marsh organic matter flow. Ecology 67, 865-874.

Peterson, B.J., Fry, B., 1987. Stable isotopes in ecosystem studies. Annual Review of Ecology and Systematics $18,293-320$.

Peterson, B.J., Howarth, R.W., 1987. Sulfur, carbon, and nitrogen isotopes used to trace organic matter flow in the salt-Marsh estuaries of Sapelo Island, Georgia. Limnology and Oceanography 32, 1195-1213.

Pritchard, D.W., 1952. Estuarine hydrography. In: Landsberg, H.E. (Ed.), Advances in Geophysics. Academic Press, New York, pp. 243-280.

Qian, Y., Kennicutt II, M.C., Svalberg, J., Macko, S.A., Bidigare, R.R., Walker, J., 1996. Suspended particulate organic matter (SPOM) in Gulf of Mexico estuaries: compound-specific isotope analysis and plant pigment compositions. Organic Geochemistry 24, 875-888. 
R Development Core Team, 2008. R: a Language and Environment for Statistical Computing. R Foundation for Statistical Computing, Vienna, Austria. http:// www.R-project.org

Raymond, P.A., Bauer, J.E., 2001. Riverine export of aged terrestrial organic matter to the North Atlantic Ocean. Nature 409, 497-500.

Riera, P., Montagna, P.A., Kalke, R.D., Richard, P., 2000. Utilization of estuarine organic matter during growth and migration by juvenile brown shrimp Penaeus aztecus in a South Texas estuary. Marine Ecology Progress Series 199, 205-216.

Riera, P., Richard, P., 1996. Isotopic determination of food sources of Crassostrea gigas along a trophic gradient in the estuarine bay of Marennes-Oléron. Estuarine, Coastal and Shelf Science 42, 347-360.

Riera, P., Richard, P., 1997. Temporal variation of $\delta^{13} \mathrm{C}$ in particulate organic matter and oyster Crassostrea gigas in Marennes-Oléron bay (France): effect of freshwater inflow. Marine Ecology Progress Series 147, 105-115.

Riera, P., Stal, L.J., Nieuwenhuize, J., Richard, P., Blanchard, G.F., Gentil, F., 1999. Determination of food sources for benthic invertebrates in a salt marsh (Aiguillon bay, France) by carbon and nitrogen stable isotopes: importance of locally produced sources. Marine Ecology Progress Series 187, 301-307.

Savoye, N., Aminot, A., Tréguer, P., Fontugne, M., Naulet, N., Kérouel, R., 2003. Dynamics of particulate organic matter $\delta^{15} \mathrm{~N}$ and $\delta^{13} \mathrm{C}$ during spring phytoplankton blooms in a macrotidal ecosystem (Bay of Seine, France). Marine Ecology Progress Series 255, 27-41.

Savoye, N., David, V., Morisseau, F., Etcheber, H., Abril, G., Billy, I., Charlier, K., Oggian, G., Derriennic, H., Sautour, B., 2012. Origin and composition of particulate organic matter in a macrotidal turbid estuary: The Gironde Estuary, France. Estuarine, Coastal and Shelf Science 108, 16-28. 
Solis, R.S., Powell, G.L., 1999. Hydrography, mixing characteristics, and residence times of Gulf of Mexico estuaries. In: Bianchi, T.S., Pennock, J.R., Twilley, R.R. (Eds.), Biogeochemistry of Gulf of Mexico Estuaries. John Wiley \& Sons, New York, pp. 29-61.

Smith, B.N., Epstein, S., 1971. Two categories of ${ }^{13} \mathrm{C} /{ }^{12} \mathrm{C}$ ratios for higher plants. Plant Physiology 47, 380-384.

Stribling, J.M., Cornwell, J.C., Currin, C., 1998. Variability of stable sulfur isotopic ratios in Spartina alterniflora. Marine Ecology Progress Series 166, 73-81.

Sullivan, M.J., Moncreiff, C.A., 1990. Edaphic algae are an important component of salt marsh foodwebs: evidence from multiple stable isotope analyses. Marine Ecology Progress Series 62, 149-159.

Teeri, J.A., Stowe, L.G., 1976. Climatic patterns and the distribution of grasses in North America. Oecologia 23, 1-12.

Thode, H.G., 1991. Sulphur isotopes in nature and the environment: an overview. In: Krouse, H.R., Grinenko, V.A. (Eds.), Stable Isotopes in the Assessment of Natural and Anthropogenic Sulphur in the Environment. John Wiley \& Sons, Chichester, pp. 1-26.

U.S. Geological Survey, 2012. National Water Information System data available on the World Wide Web (USGS Water Data for the Nation), accessed February 17, 2012, http://waterdata.usgs.gov/nwis/dvstat?

Vander Zanden, M.J., Rasmussen, J.B., 1999. Primary consumer $0^{13} \mathrm{C}$ and ${ }^{12} \mathrm{~N}$ and the trophic position of aquatic consumers. Ecology 80, 1395-1404.

Welschmeyer, N.A., 1994. Fluorometric analysis of chlorophyll $a$ in the presence of chlorophyll $b$ and pheopigments. Limnology and Oceanography 39, 1985-1992. 


\section{Tables}

Table 1: Stable isotope compositions $\left(\delta^{13} \mathrm{C}, \delta^{15} \mathrm{~N}, \delta^{34} \mathrm{~S}\right.$, mean \pm standard deviation, \%o) of the different benthic primary producers in the Mission-Aransas estuary. Sample size is displayed in parentheses.

\begin{tabular}{|c|c|c|c|c|c|}
\hline Species & Location & Date & $\delta^{13} \mathrm{C}$ & $\delta^{15} \mathrm{~N}$ & $\delta^{34} S$ \\
\hline \multicolumn{6}{|l|}{ C3 vascular plants } \\
\hline \multirow[t]{4}{*}{ Borrichia frutescens } & Station 1 & November 2010 & $-26.8 \pm 1.5(3)$ & $7.0 \pm 0.8(3)$ & $7.1 \pm 4.6(3)$ \\
\hline & & March 2011 & $-29.1 \pm 0.2(3)$ & $6.6 \pm 1.0(3)$ & $7.5 \pm 0.4(3)$ \\
\hline & & June 2011 & $-28.9 \pm 0.9(3)$ & $6.5 \pm 0.1(3)$ & $17.0 \pm 0.5(3)$ \\
\hline & Station 5 & November 2010 & $-26.8 \pm<0.1(3)$ & $5.4 \pm 0.5(3)$ & $14.2 \pm 0.7(3)$ \\
\hline Phragmites australis & Station 1 & November 2010 & $-27.2 \pm 0.3(3)$ & $9.2 \pm 0.5(3)$ & - \\
\hline \multirow[t]{3}{*}{ Salicornia virginica } & Station 1 & November 2010 & $-27.7 \pm 1.0(3)$ & $6.7 \pm 0.9(3)$ & $10.3 \pm 0.9(3)$ \\
\hline & & June 2011 & $-29.2 \pm 0.2(3)$ & $4.8 \pm 2.3(3)$ & $13.3 \pm 0.9(3)$ \\
\hline & Station 5 & November 2010 & $-28.8 \pm 0.3(3)$ & $10.0 \pm 0.4(3)$ & $12.0 \pm 0.7(3)$ \\
\hline \multirow[t]{2}{*}{ Suaeda linearis } & Station 1 & June 2011 & $-27.3 \pm 0.8(3)$ & $7.9 \pm 0.5(3)$ & $18.4 \pm<0.01(3)$ \\
\hline & Station 5 & November 2010 & $-27.8 \pm 0.2(3)$ & $8.0 \pm 0.3(3)$ & $13.7 \pm 1.7(3)$ \\
\hline Suaeda virginica & Station 1 & March 2011 & $-29.2 \pm 0.4(3)$ & $4.5 \pm 2.3(3)$ & $13.6 \pm 0.7(3)$ \\
\hline \multicolumn{6}{|l|}{ C4 vascular plants } \\
\hline Monanthochloe littoralis & Station 5 & November 2010 & $-15.5 \pm 0.9(3)$ & $6.6 \pm 1.6(3)$ & - \\
\hline \multirow[t]{7}{*}{ Spartina alterniflora } & Station 1 & November 2010 & $-13.4 \pm 0.3(3)$ & $5.5 \pm 0.5(3)$ & $7.1 \pm 4.6(3)$ \\
\hline & & March 2011 & $-12.5 \pm 0.2(3)$ & $6.0 \pm 0.6(3)$ & $2.2 \pm 3.0(3)$ \\
\hline & & June 2011 & $-13.4 \pm 0.1(3)$ & $4.6 \pm 0.8(3)$ & - \\
\hline & Station 3 & November 2010 & $-13.6 \pm 0.3(3)$ & $3.5 \pm 1.3(3)$ & $-0.8 \pm 0.5(3)$ \\
\hline & & June 2011 & $-13.5 \pm 0.4(3)$ & $3.6 \pm 0.3(3)$ & - \\
\hline & Station 4 & November 2010 & $-13.1 \pm 0.1(3)$ & $-1.1 \pm 0.6(3)$ & $-5.8 \pm 1.6(3)$ \\
\hline & Station 5 & November 2010 & $-13.3 \pm 0.1(3)$ & $2.8 \pm 1.0(3)$ & $-5.3 \pm 1.7(2)$ \\
\hline Spartina patens & Station 1 & June 2011 & $-13.6 \pm 0.3(3)$ & $7.7 \pm 0.5(3)$ & - \\
\hline Spartina spartinae & Station 1 & November 2010 & $-13.6 \pm 0.2(3)$ & $5.3 \pm 0.7(3)$ & - \\
\hline \multicolumn{6}{|l|}{ Seagrass plants } \\
\hline \multicolumn{6}{|l|}{ Halodule wrightii } \\
\hline \multirow[t]{5}{*}{ Leaves } & Station 3 & November 2010 & $-13.4 \pm 0.6(3)$ & $9.2 \pm 0.6(3)$ & $2.7 \pm 1.5(3)$ \\
\hline & & March 2011 & $-14.2 \pm 0.9(3)$ & $7.8 \pm 0.2(3)$ & $-1.5 \pm 1.5(3)$ \\
\hline & Station 4 & November 2010 & $-11.4 \pm 0.1(3)$ & $2.0 \pm 0.5(3)$ & $2.3 \pm 1.7(3)$ \\
\hline & & June 2011 & $-12.2 \pm 0.4(3)$ & $4.3 \pm 0.2(3)$ & $6.1 \pm 1.8(3)$ \\
\hline & Station 5 & November 2010 & $-11.3 \pm 0.1(4)$ & $4.4 \pm 0.2(4)$ & $-0.2 \pm 1.8(3)$ \\
\hline \multirow[t]{5}{*}{ Roots } & Station 3 & November 2010 & $-13.2 \pm 0.4(3)$ & $8.3 \pm 0.6(3)$ & $-1.4 \pm 0.4(3)$ \\
\hline & & March 2011 & $-13.8 \pm 0.3(3)$ & $7.5 \pm 0.2(3)$ & $-8.9 \pm 1.2(3)$ \\
\hline & Station 4 & November 2010 & $-11.8 \pm 0.1(3)$ & $2.3 \pm 0.8(3)$ & $-2.6 \pm 0.4(3)$ \\
\hline & & June 2011 & $-13.3 \pm 0.2(2)$ & $4.1 \pm 0.7(2)$ & $7.8 \pm 0.5(2)$ \\
\hline & Station 5 & November 2010 & $-10.9 \pm 0.5(4)$ & $4.0 \pm 0.2(4)$ & $-11.1(1)$ \\
\hline \multirow[t]{2}{*}{ Detrital matter } & Station 3 & November 2010 & $-18.1 \pm 1.9(3)$ & $7.5 \pm 0.6(3)$ & $-2.3 \pm 2.1(3)$ \\
\hline & Station 4 & November 2010 & $-11.9 \pm<0.1(3)$ & $1.8 \pm 0.3(3)$ & $0.3 \pm 2.5(3)$ \\
\hline \multicolumn{6}{|l|}{ Ruppia maritima } \\
\hline \multirow[t]{4}{*}{ Leaves } & Station 1 & March 2011 & $-12.9 \pm 0.1(3)$ & $6.2 \pm 1.1(3)$ & $6.0 \pm 1.7(3)$ \\
\hline & & June 2011 & $-13.0 \pm 0.3(3)$ & $4.4 \pm 0.2(3)$ & $1.6 \pm 0.8(3)$ \\
\hline & Station 3 & June 2011 & $-10.7 \pm 0.4(3)$ & $6.0 \pm 0.8(3)$ & $3.8 \pm 0.7(3)$ \\
\hline & Station 4 & November 2010 & $-10.9 \pm 0.3(3)$ & $4.1 \pm 0.3(3)$ & $4.6 \pm 2.7(3)$ \\
\hline
\end{tabular}




\begin{tabular}{|c|c|c|c|c|c|}
\hline \multirow[t]{4}{*}{ Roots } & Station 1 & March 2011 & $-14.7 \pm 2.1(3)$ & $3.5 \pm 0.4(3)$ & $2.5 \pm 3.0(3)$ \\
\hline & & June 2011 & $-13.4 \pm 0.5(3)$ & $3.6 \pm 0.6(3)$ & $-3.7 \pm 1.8(3)$ \\
\hline & Station 3 & June 2011 & $-11.1 \pm 0.4(3)$ & $5.0 \pm 0.5(3)$ & $-8.3 \pm 0.9(3)$ \\
\hline & Station 4 & November 2010 & $-11.1 \pm 0.5(3)$ & $2.6 \pm 0.7(3)$ & $-3.4 \pm 0.7(3)$ \\
\hline \multicolumn{6}{|l|}{ Benthic microalgae } \\
\hline \multirow[t]{6}{*}{ Diatoms } & Station 1 & November 2010 & $-19.9 \pm 0.5(3)$ & $5.3 \pm 0.1(3)$ & $5.0(1)$ \\
\hline & & March 2011 & $-14.2 \pm 0.1(3)$ & $5.0 \pm 0.1(3)$ & $8.2(1)$ \\
\hline & & June 2011 & $-13.3 \pm 0.4(9)$ & $4.2 \pm 0.6(9)$ & $5.8 \pm 1.3(8)$ \\
\hline & Station 3 & November 2010 & $-18.6 \pm 0.8(10)$ & $4.7 \pm 0.2(10)$ & $8.8 \pm 2.5(4)$ \\
\hline & & March 2011 & $-13.1 \pm 0.8(6)$ & $4.4 \pm 0.2(6)$ & $8.2(1)$ \\
\hline & & June 2011 & $-12.7 \pm 0.6(3)$ & $3.8 \pm 0.3(3)$ & $7.7(1)$ \\
\hline \multirow{6}{*}{$\begin{array}{l}\text { Oscillatoriales } 1 \\
\text { (Cyanobacteria) }\end{array}$} & Station 1 & November 2010 & $-18.2 \pm 0.6(4)$ & $0.7 \pm 0.2(4)$ & - \\
\hline & & & & & \\
\hline & & March 2011 & $-16.4 \pm 0.5(9)$ & $2.8 \pm 1.3(9)$ & $11.8 \pm 2.9(2)$ \\
\hline & & June 2011 & $-13.6 \pm 0.6(3)$ & $3.0 \pm 0.1(3)$ & $5.1 \pm 0.3(3)$ \\
\hline & Station 2 & May 2011 & $-14.4 \pm<0.1(3)$ & $-0.6 \pm 0.2(3)$ & - \\
\hline & Station 3 & June 2011 & $-12.0 \pm 0.1(3)$ & $4.8 \pm 0.1(3)$ & $8.6(1)$ \\
\hline $\begin{array}{l}\text { Oscillatoriales } 2 \\
\text { (Cyanobacteria) }\end{array}$ & Station 3 & March 2011 & $-13.2 \pm 0.1(2)$ & $3.5 \pm 0.1(2)$ & $6.2 \pm 1.6(7)$ \\
\hline Merismopedia sp. & Station 1 & November 2010 & $-21.7 \pm 0.1(4)$ & $2.8 \pm<0.1(4)$ & $4.1(1)$ \\
\hline & Station 3 & June 2011 & $-13.4 \pm 0.4(3)$ & $3.3 \pm 0.2(3)$ & $6.2 \pm 0.9(3)$ \\
\hline \multirow{2}{*}{$\begin{array}{c}\text { Benthic algae } \\
\text { (mixture cyanobacteria and } \\
\text { diatoms) }\end{array}$} & Station 3 & March 2011 & $-13.6 \pm 0.4(6)$ & $3.8 \pm 0.5(6)$ & - \\
\hline & Station 5 & November 2010 & $-15.1 \pm 0.4(4)$ & $2.4 \pm 0.1(4)$ & $4.6(1)$ \\
\hline \multirow{2}{*}{$\begin{array}{l}\text { Spirogyra sp. } \\
\text { (Charophyta) }\end{array}$} & Station 1 & November 2010 & $-17.8 \pm 0.6(7)$ & $4.2 \pm 1.2(7)$ & - \\
\hline & Station 5 & November 2010 & $-13.6 \pm 0.4(2)$ & $1.0 \pm 0.1(2)$ & - \\
\hline
\end{tabular}


Table 2: Summary of Kruskal-Wallis tests and comparisons of means for $\delta^{13} \mathrm{C}, \delta^{15} \mathrm{~N}, \delta^{34} \mathrm{~S}, \mathrm{Chl} a$ and

$\mathrm{C} / \mathrm{chl} a$ of SPOM between sampling months at each station. Stations: ARA: Aransas river, MIS: Mission river, GoM: Gulf of Mexico.

\begin{tabular}{|c|c|c|c|c|c|c|c|c|c|c|}
\hline \multirow{2}{*}{ Station } & \multicolumn{2}{|c|}{$\delta^{13} \mathrm{C}$} & \multicolumn{2}{|c|}{$\delta^{15} \mathrm{~N}$} & \multicolumn{2}{|c|}{$\delta^{34} \mathrm{~S}$} & \multicolumn{2}{|c|}{$\mathrm{Chl} a$} & \multicolumn{2}{|c|}{$\mathrm{c} / \mathrm{chl} a$} \\
\hline & $\mathrm{p}$-values & $\begin{array}{c}\text { Comparisons } \\
\text { of means }\end{array}$ & $p$-values & $\begin{array}{c}\text { Comparisons } \\
\text { of means }\end{array}$ & $p$-values & $\begin{array}{c}\text { Comparisons } \\
\text { of means }\end{array}$ & $p$-values & $\begin{array}{l}\text { Comparisons } \\
\text { of means }\end{array}$ & $p$-values & $\begin{array}{l}\text { Comparisons } \\
\text { of means }\end{array}$ \\
\hline ARA & 0.001 & $\begin{array}{l}\text { Jan }>\text { Feb } \\
\text { Feb }<\text { Aug }\end{array}$ & 0.001 & $\begin{array}{l}\text { Feb }>\text { Jul } \\
\text { Feb }>\text { Aug }\end{array}$ & 0.025 & Nov $>$ Feb & 0.001 & $\begin{array}{l}\text { Dec }<\text { Feb } \\
\text { Jan }<\text { Feb } \\
\text { Jan }<\text { Mar }\end{array}$ & 0.008 & Jan $>$ Feb \\
\hline MIS & 0.001 & $\begin{array}{l}\text { Nov }<\text { Jan } \\
\text { Dec }<\text { Jan }\end{array}$ & 0.001 & Nov $>$ Jan & 0.016 & - & 0.004 & $\begin{array}{l}\text { Jan }<\text { Jul } \\
\text { Jan }<\text { Jun }\end{array}$ & 0.004 & $\begin{array}{l}\text { Jan }>\text { Jun } \\
\text { Jan }>\text { Jul }\end{array}$ \\
\hline Station 1 & 0.001 & Jan $<$ Apr & 0.004 & $\begin{array}{l}\text { Dec }>\text { Aug } \\
\text { Jun }>\text { Aug }\end{array}$ & 0.008 & - & 0.001 & $\begin{array}{l}\text { Nov }>\text { Dec } \\
\text { Dec }<\text { Apr }\end{array}$ & 0.003 & Jan $<$ Feb \\
\hline Station 2 & 0.001 & $\begin{array}{l}\text { Nov }<\text { Aug } \\
\text { Jan }<\text { Aug }\end{array}$ & 0.004 & $\begin{array}{c}\text { Nov }>\text { Mar } \\
\text { Nov }>\text { Jul }\end{array}$ & 0.017 & - & 0.001 & $\begin{array}{c}\text { Jan }<\text { Mar } \\
\text { Mar }>\text { May }\end{array}$ & 0.002 & $\mathrm{Dec}>\mathrm{Feb}$ \\
\hline Station 3 & 0.004 & - & 0.043 & - & 0.087 & - & 0.006 & - & 0.016 & Jan $<$ Feb \\
\hline Station 4 & 0.002 & $\begin{array}{l}\text { Nov }<\text { Apr } \\
\text { Jan }<\text { Apr }\end{array}$ & 0.002 & $\begin{array}{l}\text { Nov }>\text { Jul } \\
\text { Jan }>\text { Jul }\end{array}$ & 0.060 & - & 0.034 & Apr $>$ Jul & 0.003 & $\begin{array}{l}\text { Dec }<\text { Jul } \\
\text { Jan }<\text { Jul }\end{array}$ \\
\hline Station 5 & 0.006 & - & 0.007 & - & 0.049 & - & 0.002 & $\begin{array}{l}\text { Jan }>\text { Jul } \\
\text { Apr }>\text { Jul }\end{array}$ & 0.007 & Nov $>$ Apr \\
\hline GoM & 0.011 & - & 0.006 & - & 0.118 & - & 0.009 & $\begin{array}{l}\text { Feb }>\text { May } \\
\text { Feb }>\text { Aug }\end{array}$ & 0.014 & - \\
\hline
\end{tabular}


Table 3: Summary of Kruskal-Wallis tests and comparisons of means for $\delta^{13} \mathrm{C}, \delta^{15} \mathrm{~N}, \delta^{34} \mathrm{~S}, \mathrm{Chl} a$ and

C/chl $a$ of SPOM between sampling stations for each month. Stations: ARA: Aransas river, MIS:

Mission river, St. 1 to 5: Stations 1 to 5, GoM: Gulf of Mexico.

\begin{tabular}{|c|c|c|c|c|c|c|c|c|c|c|}
\hline \multirow[b]{2}{*}{ Station } & \multicolumn{2}{|c|}{$\delta^{13} \mathrm{C}$} & \multicolumn{2}{|c|}{$\delta^{15} \mathrm{~N}$} & \multicolumn{2}{|c|}{$\delta^{34} \mathrm{~S}$} & \multicolumn{2}{|c|}{$\mathrm{Chl} a$} & \multicolumn{2}{|c|}{$\mathrm{C} / \mathrm{chl} a$} \\
\hline & $\mathrm{p}$-values & $\begin{array}{c}\text { Comparisons } \\
\text { of means }\end{array}$ & p-values & $\begin{array}{l}\text { Comparisons } \\
\text { of means }\end{array}$ & $p$-values & $\begin{array}{l}\text { Comparisons } \\
\text { of means }\end{array}$ & $p$-values & $\begin{array}{c}\text { Comparisons } \\
\text { of means }\end{array}$ & $p$-values & $\begin{array}{l}\text { Comparisons } \\
\text { of means }\end{array}$ \\
\hline November 10 & 0.007 & $\begin{array}{l}\text { MIS }<\text { St. } 5 \\
\text { MIS }<\text { GoM }\end{array}$ & 0.005 & ARA $>$ St. 1 & 0.039 & - & 0.004 & St. $1>$ St. 5 & 0.004 & $\begin{array}{l}\text { ARA }<\text { St. } 5 \\
\text { St. } 2<\text { St. } 5\end{array}$ \\
\hline December 10 & 0.003 & $\begin{array}{l}\text { MIS }<\text { St. } 5 \\
\text { MIS }<\text { GoM }\end{array}$ & 0.096 & - & 0.017 & - & 0.030 & - & 0.030 & St. $2>$ St. 4 \\
\hline January 11 & 0.003 & $\begin{array}{l}\text { St. } 2<\text { St. } 5 \\
\text { St. } 2<\text { GoM }\end{array}$ & 0.003 & MIS $<$ St. 4 & 0.013 & - & 0.003 & MIS < St. 1 & 0.012 & - \\
\hline February 11 & 0.002 & ARA $<$ GoM & 0.007 & ARA $<$ MIS & 0.004 & ARA $<$ St. 5 & 0.002 & $\begin{array}{l}\text { ARA }>\text { MIS } \\
\text { ARA }>\text { St. } 5\end{array}$ & 0.002 & ARA $<$ St. 3 \\
\hline March 11 & 0.003 & ARA $<$ St. 5 & 0.006 & ARA $<$ MIS & 0.009 & $\mathrm{MIS}<\mathrm{GoM}$ & 0.003 & $\begin{array}{l}\text { ARA }>\text { MIS } \\
\text { ARA }>\text { St. } 5\end{array}$ & 0.004 & $\begin{array}{l}\text { ARA }<\text { St. } 1 \\
\text { ARA }<\text { St. } 2\end{array}$ \\
\hline April 11 & 0.004 & ARA $<$ St. 4 & 0.008 & ARA $>$ St. 1 & 0.013 & - & 0.003 & MIS < St. 1 & 0.012 & ARA $<$ St. 1 \\
\hline May 11 & 0.002 & $\begin{array}{l}\text { ARA }<\text { St. } 5 \\
\text { ARA }<\text { GoM }\end{array}$ & 0.003 & ARA $>$ MIS & 0.025 & - & 0.007 & $\begin{array}{l}\text { ARA }>\text { St. } 5 \\
\text { ARA }>\text { GoM }\end{array}$ & 0.074 & ARA $<$ St. 3 \\
\hline June 11 & 0.005 & - & 0.010 & ARA $>$ MIS & 0.041 & - & 0.006 & MIS > St. 5 & 0.015 & - \\
\hline July 11 & 0.030 & - & 0.006 & $\begin{array}{c}\text { ARA }<\text { MIS } \\
\text { ARA }<\text { GoM }\end{array}$ & 0.008 & - & 0.003 & $\begin{array}{l}\text { ARA }>\text { St. } 5 \\
\text { MIS }>\text { St. } 5\end{array}$ & 0.009 & MIS < St. 5 \\
\hline August 11 & 0.007 & - & 0.002 & $\begin{array}{l}\text { ARA }<\text { St. } 3 \\
\text { St. } 1<\text { St. } 3\end{array}$ & 0.174 & - & 0.002 & $\begin{array}{l}\text { ARA > St. } 5 \\
\text { ARA > GoM }\end{array}$ & 0.070 & - \\
\hline
\end{tabular}




\section{Figure captions}

Figure 1: Location of the Mission-Aransas estuary and of the sampling stations.

Figure 2: Salinity (full and dotted lines), monthly inputs of particulate organic carbon from Aransas and Mission rivers and total freshwater inflow (i. e., Mission and Aransas rivers, shaded curve) in the Mission-Aransas estuary from September 2010 to December 2011. ARA: Aransas river, MIS: Mission river, St. 1 to 5: Stations 1 to 5, GoM: Gulf of Mexico. Stars represent missing data.

Figure 3: $\delta^{13} \mathrm{C}$ and $\delta^{34} \mathrm{~S}$ values of primary producers and SPOM in the Mission-Aransas estuary. SPOM values are means \pm standard deviations of samples collected from November 2010 to August 2011. Primary producer values are means of all samples collected in the Mission-Aransas estuary from November 2010 to August 2011 (see table 1 for standard deviations). ARA: Aransas river, MIS: Mission river, St. 1 to 5: Stations 1 to 5, GoM: Gulf of Mexico.

Figure 4: $\delta^{13} \mathrm{C}$ values of benthic microalgae and salinities of sampling stations in the Mission-Aransas estuary at the sampling dates.

Figure 5: $\delta 13 \mathrm{C}, \delta 15 \mathrm{~N}, \delta 34 \mathrm{~S}$ values (full and dotted lines) and total freshwater inflow (i. e., Mission and Aransas rivers, shaded curve) in the Mission-Aransas estuary from September 2010 to December 2011. ARA: Aransas river, MIS: Mission river, St. 1 to 5: Stations 1 to 5, GoM: Gulf of Mexico.

Figure 6: Chlorophyll a concentration ( $\mu$ g.l-1), C/chlorophyll $a$ ratios (full and dotted lines) and total freshwater inflow (i. e., Mission and Aransas rivers, shaded curve) in the Mission-Aransas estuary from September 2010 to December 2011. ARA: Aransas river, MIS: Mission river, St. 1 to 5: Stations 1 to 5, GoM: Gulf of Mexico. 
Figure 7: Relationship between freshwater inflow and stable isotope composition of the SPOM in the secondary bay of the Mission-Aransas estuary (i.e., Copano bay). Two scenarios are considered (i.e., drought, rain event) in order to compute the averaged stable isotope composition of the SPOM and the threshold of freshwater inflow for both scenarios. Data used in this figure are issued from our survey and from the survey carried out by Mooney and McClelland (2012). 
Figure 1

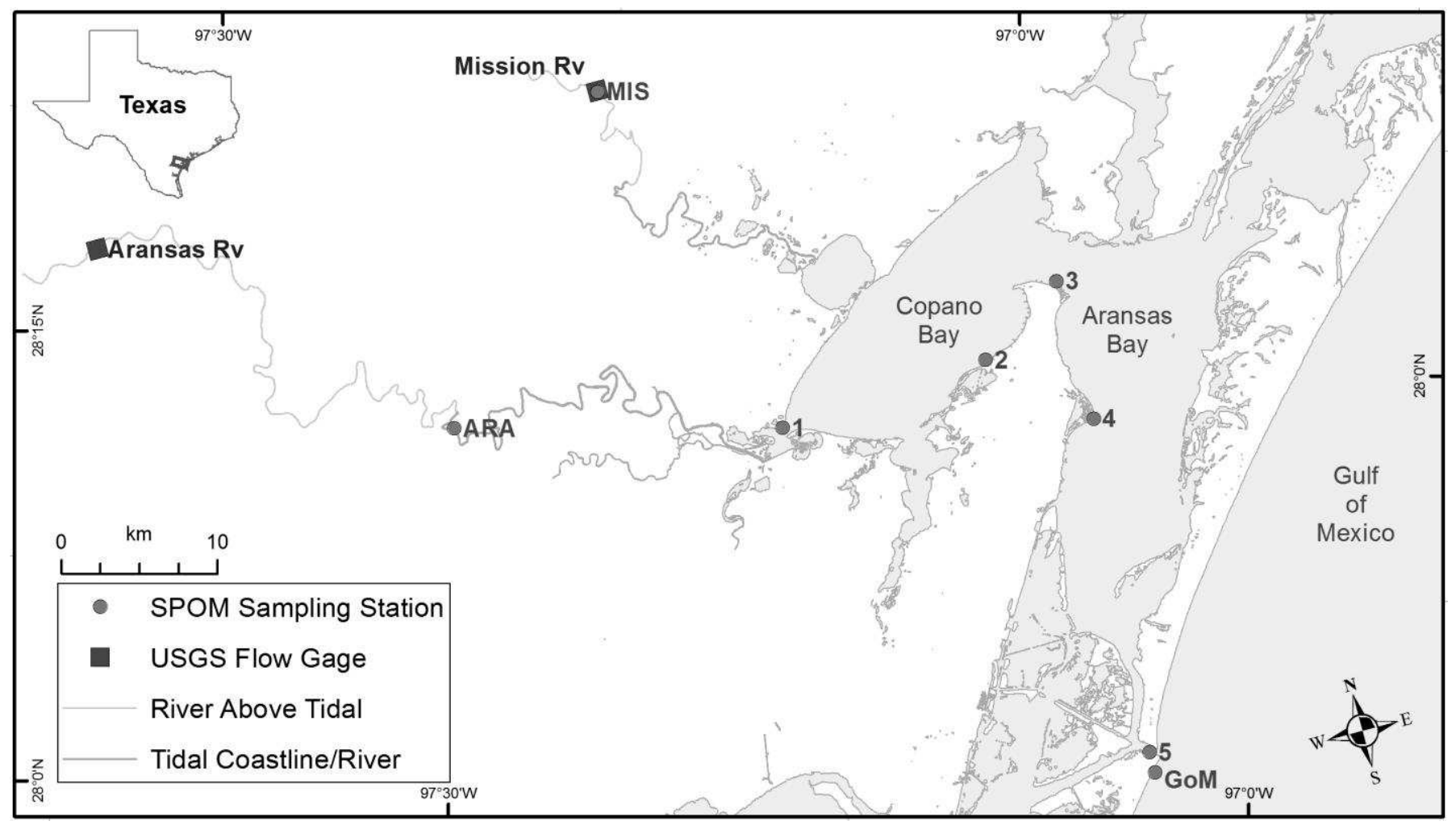


Figure 2
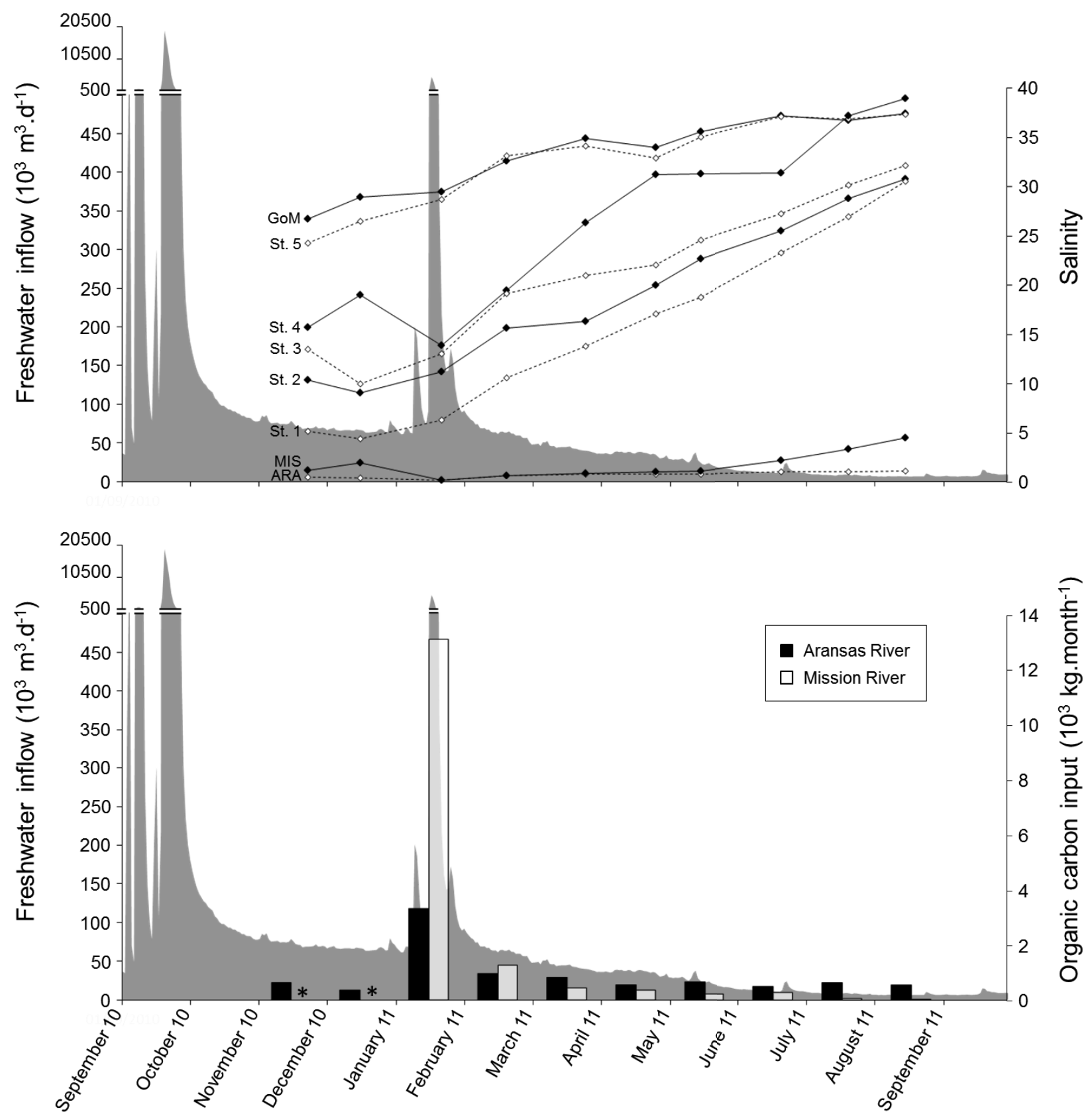
Figure 3

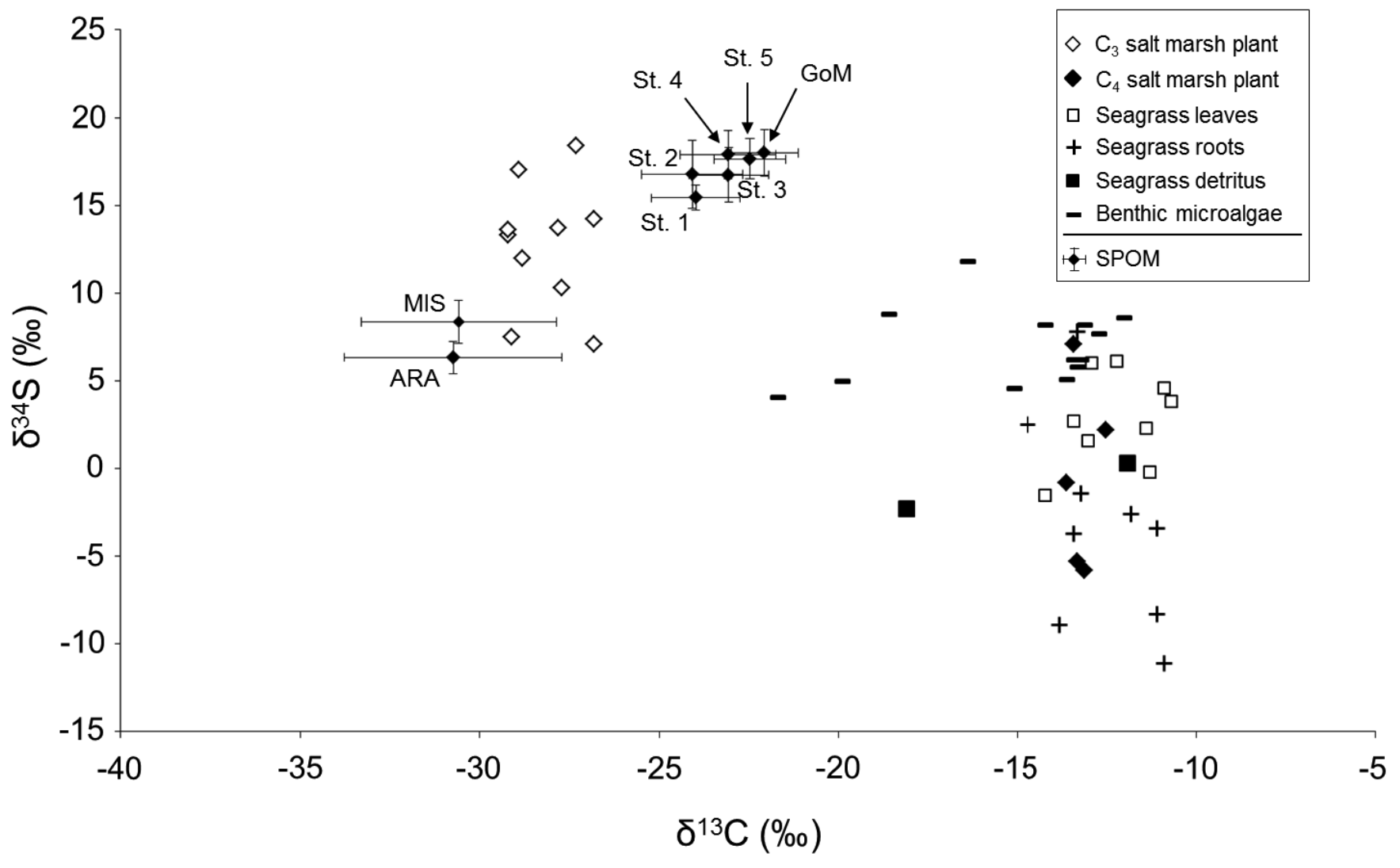


Figure 4

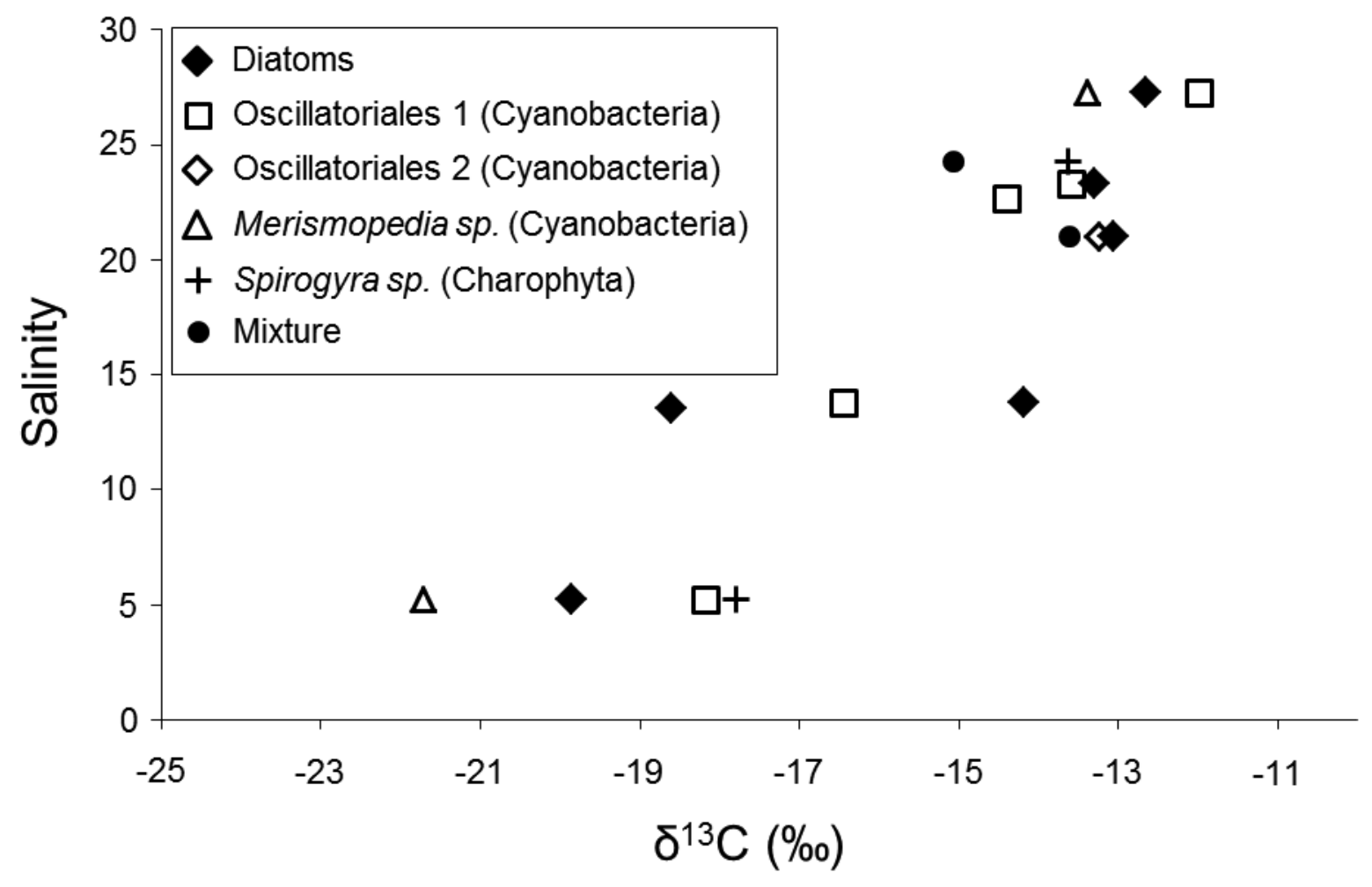


Figure 5
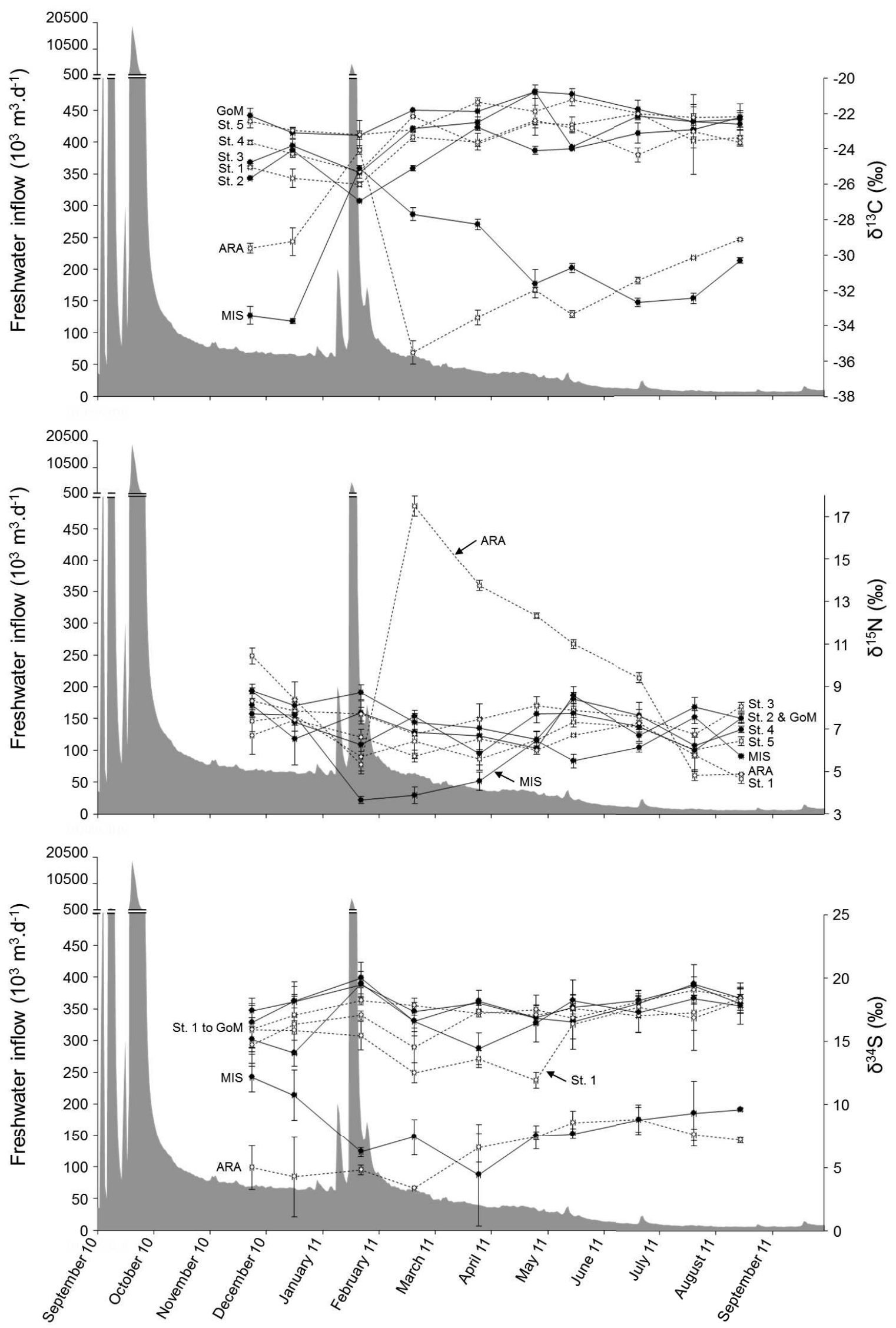
Figure 7

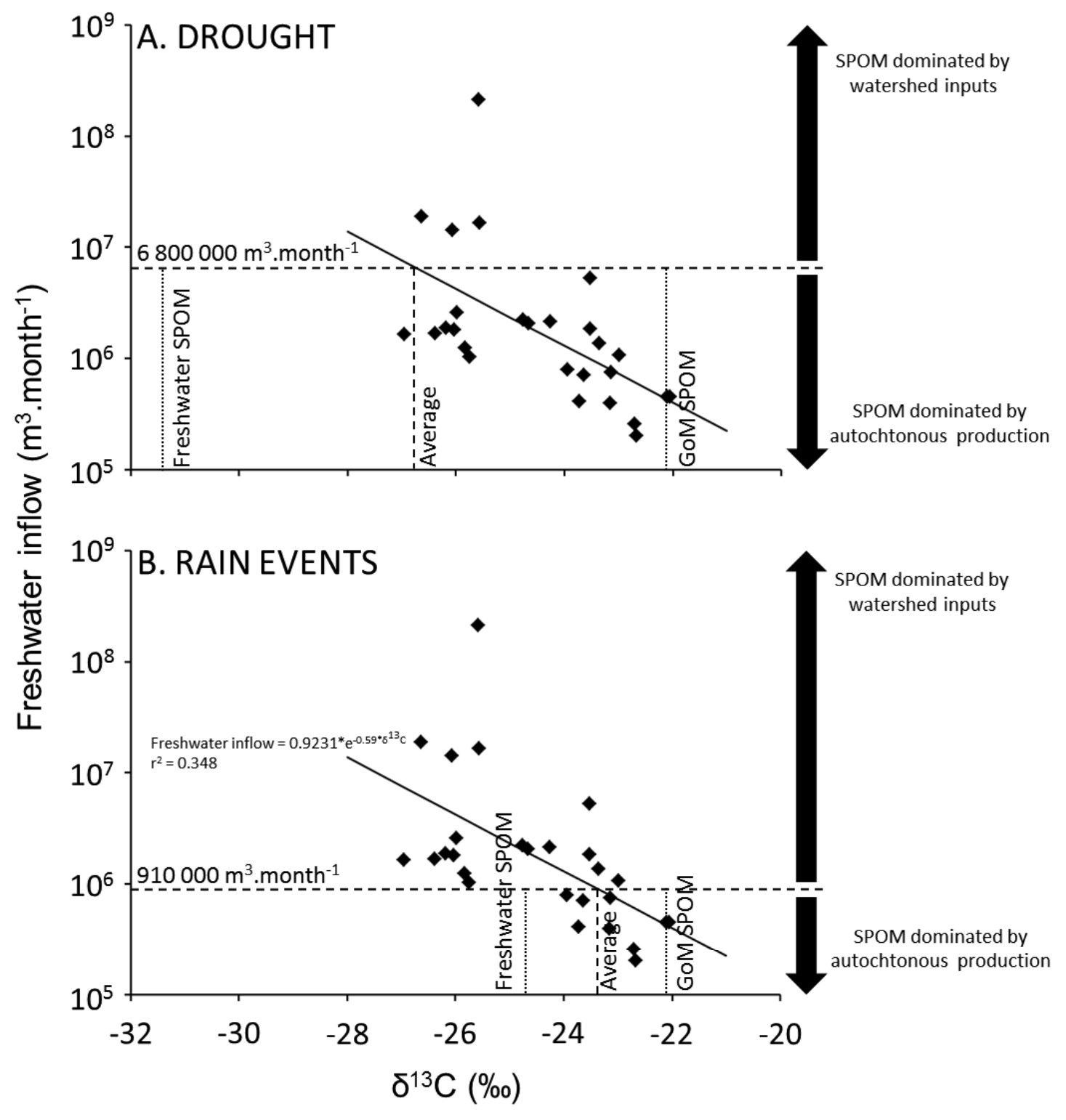


Figure 6
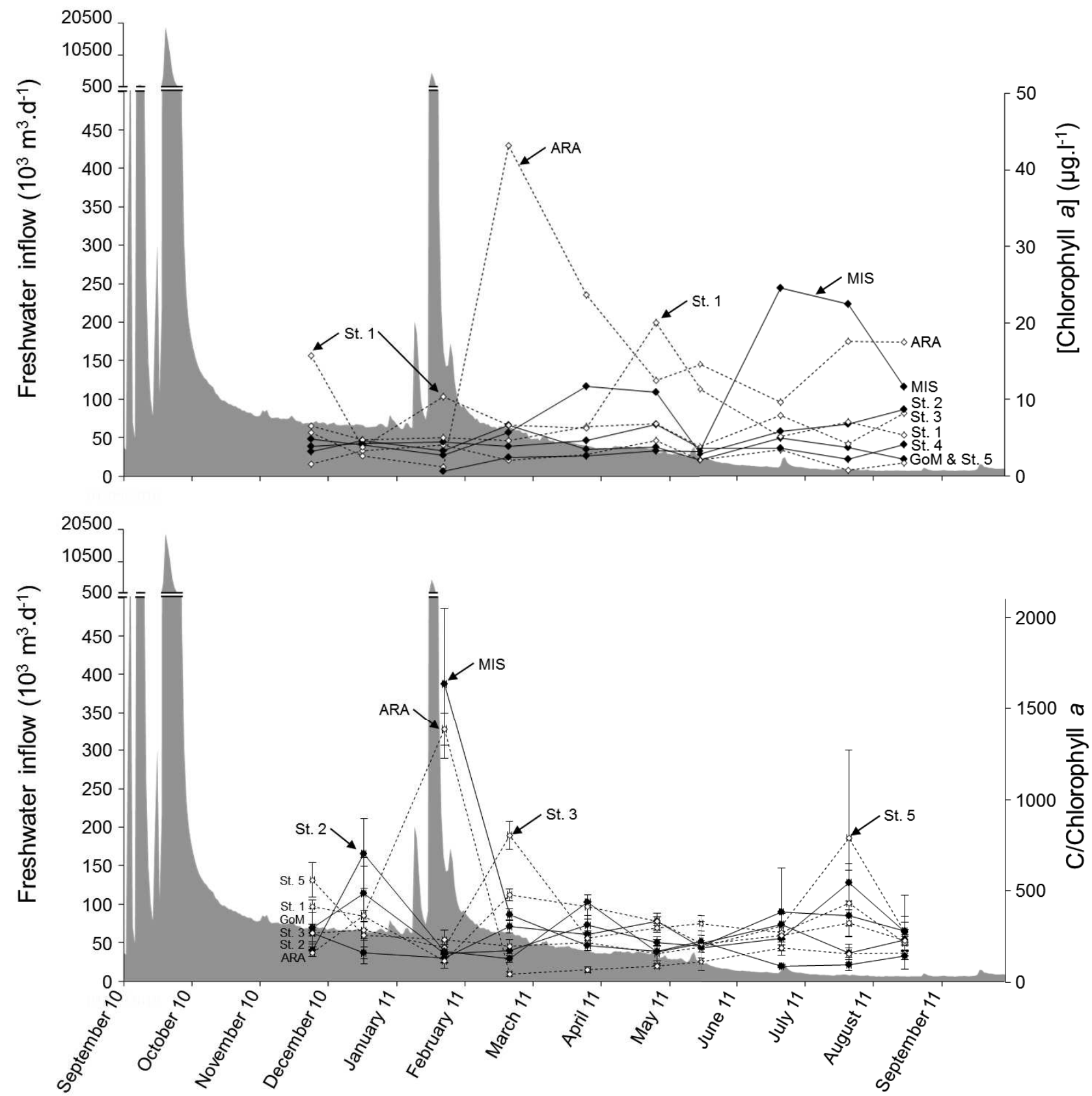
jupplementary material for online publication only

Elick here to download Supplementary material for online publication only: Supplementary_data_Lebreton_et_al.docx 